\title{
Photochemical Nitric Oxide Precursors: Synthesis, Photochemistry, and Ligand Substitution Kinetics of Ruthenium Salen Nitrosyl and Ruthenium Salophen Nitrosyl Complexes ${ }^{1}$
}

\author{
Carmen F. Works, Christoph J. Jocher, ${ }^{2}$ Gwen D. Bart, Xianhui Bu, and Peter C. Ford* \\ Department of Chemistry and Biochemistry, University of California, Santa Barbara, \\ Santa Barbara, California 93106
}

Received April 1, 2002

\begin{abstract}
Described are syntheses, characterizations, and photochemical reactions of the nitrosyl complexes Ru(salen)$(\mathrm{ONO})(\mathrm{NO})\left(\mathrm{I}\right.$, salen $=N, N$-ethylenebis(salicylideneiminato) dianion), Ru(salen)(Cl)(NO) (II), Ru('Bu${ }_{4}$ salen)(Cl)(NO) (III, 'Bus salen = N,N'-ethylenebis(3,5-di-tert-butylsalicylideneiminato) dianion), Ru('Bu4s salen)(ONO)(NO) (IV), $\mathrm{Ru}$ ('Bu $\mathrm{B}_{2}$ salophen)(Cl)(NO) ( $\mathrm{V}$, 'Bu $\mathrm{H}_{2}$ salophen $=N, N^{\prime}$-1,2-phenylenediaminebis(3-tert-butylsalicylideneiminato) dianion), and $\mathrm{Ru}\left({ }^{\prime} \mathrm{Bu}_{4}\right.$ salophen)(Cl)(NO) (VI, 'Bu 4 salophen $=N, N$-1,2-phenylenebis(3,5-di-tert-butylsalicylideneiminato) dianion). Upon photolysis, these $\mathrm{Ru}(\mathrm{L})(\mathrm{X})(\mathrm{NO})$ compounds undergo NO dissociation to give the ruthenium(III) solvento products $\mathrm{Ru}(\mathrm{L})(\mathrm{X})(\mathrm{Sol})$. Quantum yields for $365 \mathrm{~nm}$ irradiation in acetonitrile solution fall in a fairly narrow range $(0.055-$ $0.13)$ but decreased at longer $\lambda_{\text {irr }}$. The quantum yield $\left(\lambda_{\text {irr }}=365 \mathrm{~nm}\right)$ for NO release from the water soluble complex $\left[\mathrm{Ru}\left(\right.\right.$ salen) $\left.\left(\mathrm{H}_{2} \mathrm{O}\right)(\mathrm{NO})\right] \mathrm{Cl}(\mathrm{VII})$ was 0.005 in water. Kinetics of thermal back-reactions to re-form the nitrosyl complexes demonstrated strong solvent dependence with second-order rate constants $k_{\mathrm{NO}}$ varying from $5 \times 10^{-4}$ $\mathrm{M}^{-1} \mathrm{~s}^{-1}$ for the re-formation of II in acetonitrile to $5 \times 10^{8} \mathrm{M}^{-1} \mathrm{~s}^{-1}$ for re-formation of III in cyclohexane. Pressure and temperature effects on the back-reaction rates were also examined. These results are relevant to possible applications of photochemistry for nitric oxide delivery to biological targets, to the mechanisms by which NO reacts with metal centers to form metal-nitrosyl bonds, and to the role of photochemistry in activating similar compounds as catalysts for several organic transformations. Also described are the X-ray crystal structures of I and V.
\end{abstract}

\section{Introduction}

Over the past decade there has been considerable interest in the chemistry and biochemistry of nitric oxide (NO, nitrogen monoxide), owing to the discovery of diverse roles in mammalian biology, ${ }^{3}$ examples being as a bioregulatory molecule in the blood pressure control and as a toxic agent produced in immune response to pathogens. ${ }^{4}$ Numerous

* To whom correspondence should be addressed. E-mail: ford@ chem.ucsb.edu.

(1) (a) Taken in part from the part from the Ph.D. Dissertation of C.F.W., University of California, Santa Barbara, CA, 2001. (b) Aspects of this work were reported in a preliminary communication: Works, C. F.; Ford, P. C. J. Am. Chem. Soc. 2000, 122, 7592-7593.

(2) Visiting Diplom student from the Chemisches Institut, Westfälische Wilhelms Universität, Münster, Germany.

(3) (a) Moncada, S.; Palmer, R. M. J.; Higgs, E. A. Pharmacol. Rev. 1991, 43, 109-142. (b) Feldman, P. L.; Griffith, O. W.; Stuehr, D. J. Chem. Eng. News 1993, 71 (10), 26-38. (c) Butler, A. R.; Williams, D. L. Chem. Soc. Rev. 1993, 233-241. (d) Methods in Nitric Oxide Research; Feelisch, M., Stamler, J. S., Eds.; John Wiley and Sons: Chichester, England, 1996; and references therein. (e) Wink, D. A.; Hanbauer, I.; Grisham, M. B.; Laval, F. F.; Nims, R. W.; Laval, J.; Cook, J.; Pacelli, R.; Liebmann, J.; Krishna, M.; Ford, P. C.; Mitchell, J. B. Curr. Top. Cell. Regul. 1996, 34, 159-187.

3728 Inorganic Chemistry, Vol. 41, No. 14, 2002 disease states have been coupled to the under- or overproduction of NO, and as a consequence, there has been considerable interest in biomedical strategies for the selective delivery and for selective trapping of NO. ${ }^{4,5}$ For example, such NO delivery has been claimed to have potential therapeutic value in treatments of such cardiovascular events as stroke and heart attack $^{5 \mathrm{a}}$ as well as in treatment of cancer. ${ }^{5 \mathrm{~b}}$ In this context, ongoing studies here and elsewhere have been concerned with the preparation and mechanistic evaluation of compounds having the potential for photochemically activated NO delivery to specific physiological targets. ${ }^{6}$ For example, our experiments have shown that NO release

(4) (a) Nitric Oxide: Biology and Pathobiology; Ignarro, L. J., Ed.; Academic Press: San Diego, CA, 2000. (b) Nitric Oxide and Infection; Fang, F. C., Ed.; Kluwer Academic/Plenum Publishers: New York, 1999.

(5) (a) Yamamoto, T.; Kakar, N. Rani; Vina, E. R.; Johnson, P. E.; Bing, R. J. Life Sci. 2000, 67, 839-846; Proc. Soc. Exp. Biol. Med. 2000, 225, 200-206. (b) Pervin, S.; Singh, R.; Gau, C.-Li.; Edamatsu, H.; Tamanoi, F.; Chaudhuri, G. Cancer Res. 2001, 61, 4701-4706. (c) Wink, D. A.; Vodovotz, Y.; Laval, J.; Laval, F.; Dewhirst, M. W.; Mitchell, J. B. Carcenogenesis 1998, 19, 711-721.

10.1021/ic020248k CCC: $\$ 22.00$ (c) 2002 American Chemical Society Published on Web 06/06/2002 


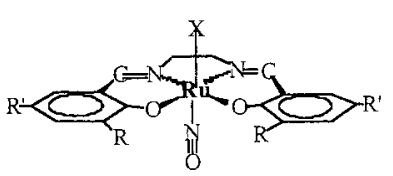

$\mathrm{Ru}(\mathrm{R}-\mathrm{salen})(\mathrm{X})(\mathrm{NO})$

$$
\begin{array}{ll}
\text { I: } & \mathrm{R}=\mathrm{H}, \mathrm{X}=\mathrm{ONO}^{\circ} \\
\text { II: } & \mathrm{R}=\mathrm{H}, \mathrm{X}=\mathrm{Cl}^{-} \\
\text {III: } & \mathrm{R}={ }^{t} \mathrm{Bu}, \mathrm{X}=\mathrm{Cl}^{\circ} \\
\text { IV: } & \mathrm{R}={ }^{\mathrm{t}} \mathrm{Bu}, \mathrm{X}=\mathrm{ONO}^{\circ} \\
\text { VII: } & \mathrm{R}=\mathrm{H}, \mathrm{X}=\mathrm{H}_{2} \mathrm{O}
\end{array}
$$

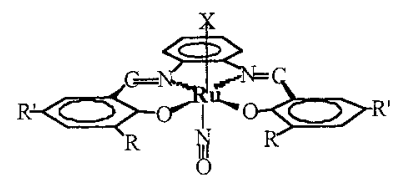

$\mathrm{Ru}(\mathrm{R}-\mathrm{salophen})(\mathrm{X})(\mathrm{NO})$

$\mathrm{V}: \mathrm{R}={ }^{\mathrm{t}} \mathrm{Bu}, \mathrm{R}^{\prime}=\mathrm{H}, \mathrm{X}=\mathrm{Cl}$

VI: $\quad \mathrm{R}=\mathrm{R}^{\prime}={ }^{\prime} \mathrm{Bu}, \mathrm{X}=\mathrm{Cl}^{-}$
Figure 1. Compounds studied.

induced by photolysis of iron thiol nitrosyl clusters absorbed into V79 Chinese hamster cells enhances $\gamma$-radiation killing of such cells under hypoxic (oxygen deficient) conditions. ${ }^{6 \mathrm{~b}}$

Among compounds under investigation as NO donors are nitrosyl complexes of ruthenium porphyrins. ${ }^{7}$ These are thermally quite stable but are photochemically active toward NO release. ${ }^{8}$ The relative stability of ruthenium nitrosyls has also drawn attention to possible applications of other ruthenium systems, such as amine complexes as carriers for NO delivery to biological targets ${ }^{9}$ and polydentate carboxylate complexes as NO scavengers under conditions of physiological overproduction. ${ }^{10}$ In this context, the present studies explore a different synthetic platform to prepare photoactive ruthenium nitrosyls, namely, the salen-type complexes $\mathrm{Ru}(\mathrm{R}$-salen)(X)(NO) and the related salophentype complexes $\mathrm{Ru}(\mathrm{R}$-salophen)(X)(NO) (Figure 1) (where $\mathrm{R}$-salen is a derivative of the $N, N^{\prime}$-ethylenebis(salicylideneiminato) dianion and R-salophen is a derivative of the $N, N^{\prime}$ 1,2-phenylenebis(salicylideneiminato) dianion). Described here are quantitative studies of photochemical NO labilization from several such complexes (e.g., eq 1).

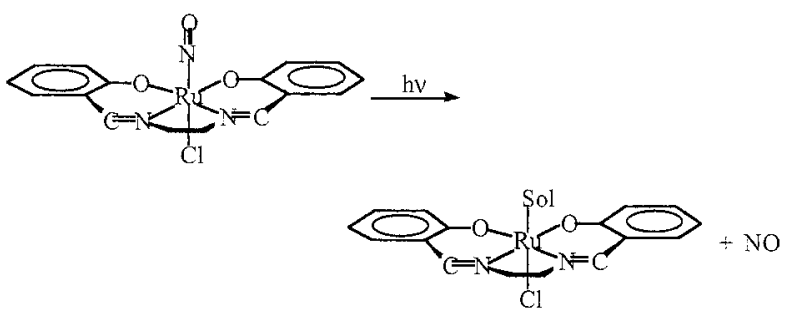

The principal targets for NO under bioregulatory conditions are metal centers, ${ }^{11} \mathrm{NO}$ activation of the ferro-heme enzyme soluble guanylyl cyclase (sGC) being the best

(6) (a) Bourassa, J.; DeGraff, W.; Kudo, S.; Wink, D. A.; Mitchell, J. B.; Ford, P. C. J. Am. Chem. Soc. 1997, 119, 2853-2860. (b) Ford, P. C.; Bourassa, J.; Miranda, K.; Lee, B.; Lorkovic, I.; Boggs, S.; Kudo, S.; Laverman, L Coord. Chem. Rev. 1998, 171, 185-202. (c) Namiki, S.; Kaneda, F.; Ikegami, M.; Arai, T.; Fujimori, K.; Asada, S.; Hama, H.; Kasuyua, Y.; Goto, K. Bioorg. Med. Chem. 1999, 7, 1695-1702. Fukuhar, K.; Kurihara, M.; Miyata, N. J. Am. Chem. Soc. 2001, 123, 8662-8666.

(7) (a) Miranda, K. M.; Bu, X.; Lorkovic, I.; Ford, P. C. Inorg. Chem. 1997, 36, 4838-4848. (b) Kadish, K. M.; Adamian, V. A.; Caemelbecke, E. V.; Tan, Z.; Tagliatesta, P.; Bianco, P.; Boschi, T.; Yi, G.B.; Khan, M. A.; Richter-Addo, G. B. Inorg. Chem. 1996, 35, $1343-$ 1348. (c) Bohle, D. S.; Goodson, P. A.; Smith, B. D. Polyhedron 1996 15, 3147-3150. (d) Yi, G.-B.; Khan, M. A.; Richter-Addo, G. B. Inorg. Chem. 1996, 35, 3453-3454. (f) Bohle, D. S., Hung, C.-H.; Smith, B. D. Inorg. Chem. 1998, 37, 5798-5706.

(8) Lorkovic, I. M.; Miranda, K. M.; Lee, B.; Bernhard, S.; Schoonover J. R.; Ford, P. C. J. Am. Chem. Soc. 1998, 120, 116474-11683. characterized example. ${ }^{12} \mathrm{NO}$ is also an inhibitor of metalloenzymes such as cytochrome oxidase, ${ }^{13}$ nitrile hydrase, ${ }^{14}$ and catalase presumably by attack at the heme centers of these to form nitrosyl complexes. A huge range in reaction rates of heme proteins with NO have been found, ${ }^{16}$ so a mechanistic understanding of the formation and breaking of metal nitrosyl bonds is essential to understanding the in vivo chemistry of nitric oxide. A key question is the following: does the free radical nature of this ligand play a special role in the dynamics of NO substitutions into the metal coordination sphere? Although interest in this reaction has grown, ${ }^{17}$ there were few quantitative studies of metal nitrosyl formation mechanisms before our activation parameter studies of NO reactions with water soluble ferri- and ferro-heme porphyrins. ${ }^{18}$ An exception was an early investigation of the reaction with the ruthenium(III) amine complex $\mathrm{Ru}\left(\mathrm{NH}_{3}\right)_{6}{ }^{3+}$ (eq 2). ${ }^{19}$ The kinetics were interpreted in terms of an

(9) (a) Lang, D. R.; Davis, J. A.; Lopes, L. G. F.; Ferro, A. A.; Vasconcellos, L. C. G.; Franco, D. W.; Tfouni, E.; Wieraszko, A.; Clarke, M. J. Merkert, Inorg. Chem. 2000, 39, 2294-2300. (b) Wieraszko, A.; Clarke, M. J.; Lang, D. R.; Lopes, L. G. F.; Franco, D. W. Life Sci. 2001, 68, 1535-1544. (c) Slocik, J. M.; Ward, M. S.; Somayajula, K. V.; Shepherd, R. E. Transition Met. Chem. 2001, 26, 351-364. (d) Carter T. D.; Bettache N.; Ogden D. Br. J. Pharmacol. 1997, 122, 971-3. (e) Borges, S. D. S.; Davanzo, C. U.; Castellano, E. E.; Zschpector, J.; Silva, S. C.; Franco, D. W. Inorg. Chem. 1998, 37, 2670-2677.

(10) (a) Fricker, Simon P. Expert Opin. Invest. Drugs 1999, 8, 12091222. (b) Fricker, S. P.; Slade, E.; Powell, N. A.; Vaughan, O. J.; Henderson, G. R.; Murrer, B. A.; Megson, I. L.; Bisland, S. K.; Flitney, F. W. Br. J. Pharmacol. 1997, 122, 1441-1449.

(11) (a) Traylor, T.; Sharma, V. S. Biochemistry 1992, 31, 2847-2849. (b) Radi, R. Chem. Res. Toxicol. 1996, 9, 828-835.

(12) (a) Kim, S.; Deinum, G.; Gardner, M. T.; Marletta, M. A.; Babcock, G. T. J. Am. Chem. Soc. 1996, 118, 8769 and references therein. (b) Burstyn, J. N.; Yu, A. E.; Dierks, E. A.; Hawkins, B. K.; Dawson, J. H. Biochemistry 1995, 34, 5896.

(13) Cleeter, M. W. J.; Cooper, J. M.; Darley-Usmar, V. M., Moncada, S.; Scapira, A. H. V. FEBS Lett. 1994, 345, 50-54. (b) Minamiyama, Y.; Takemura, S.; Imaoka, S.; Funae, Y.; Tanimoto, Y.; Inoue, M. J. Pharmacol. Exp. Ther. 1997, 283, 1479.

(14) (a) Noguchi, T.; Hoshino, M.; Tsujimura, M.; Odaka, M.; Inoue, Y. Endo, I. Biochemistry 1996, 35, 16777. (b) Odaka, M.; Fujii, K.; Hoshino, M.; Noguchi, T.; Tsujimura, M.; Nagashima, S,; Yohda, M.; Nagamune, T.; Inoue, Y.; Endo, I. J. Am. Chem. Soc. 1997, 119, 3785 (c) Tsujimura, M.; Dohmae, N.; Odaka, M.; Chijimatsu, M.; Takio, K.; Yohda, M.; Hoshino, M.; Nagashima, S.; Endo, I. J. Biol. Chem. 1997, 272, 29454

(15) Brown, G. E. Eur. J. Biochem. 1995, 232, 188-191.

(16) (a) Tamura, M.; Kobayashi, K.; Hayashi, K. FEBS Lett. 1978, 88, 124-126. (b) Rose, E. J.; Hoffman, B. J. Am. Chem. Soc. 1983, 105 2866-2873. (c) Cornelius, P. A.; Hochstrasser, R. M.; Steele, A. W. J. Mol. Biol. 1983, 163, 119-128. (d) Jongeward, K. A.; Magde, D.; Taube, D. J.; Marsters, J. C.; Traylor, T. G.; Sharma, V. S. J. Am. Chem. Soc. 1988, 110, 380-387. Yoshimura, T.; Suzuki, S.; Nakahara, A.; Iwasaki, H.; Masuko, M.; Matsubara, T. Biochemistry 1986, 22 , 3897-3902. (e) Petrich, J. W.; Poyart, C.; Martin, J. L. Biochemistry 1988, 27, 4049. (f) Hoshino, M. Ozawa, K.; Seki, H.; Ford, P. C. J. Am. Chem. Soc. 1993, 115, 9568-9575. (g) Duprat, A. F.; Traylor, T. G.; Wu, G.-Z.; Coletta, M.; Sharma, V. S.; Walda, K. N.; Magde, D. Biochemistry 1995, 34, 2634-2644. (h) Bohle, D. S.; Hung, Ch.H. J. Am. Chem. Soc. 1995, 117, 9584-9585. (i) Gordunov, N. V.; Osipov, A. N.; Day, W. B.; Zayas-River, B.; Kagan, V. E.; Elsayed, N. M. Biochemistry 1995, 34, 6689-6699.

(17) (a) Laverman, L. E.; Wanat, A.; Oszajca, J.; Stochel, G.; Ford, P. C. van Eldik, R. J. Am. Chem. Soc. 2001, 123, 285-293. (b) Wolak, M.; Zahl, A.; Schneppensieper, T.; Stochel, G.; van Eldik, R. J. Am. Chem. Soc. 2001, 123, 9780-9791. (c) George, S. J., Andrew, C. R.; Larson, D. M.; Thorneley, R. N. F.; Eady, R. R. J. Am. Chem. Soc. 2001, 123, 9683-9684

(18) (a) Laverman, L. E.; Hoshino, M.; Ford, P. C. J. Am. Chem. Soc. 1997, 119, 12663-12664. (b) Laverman, L. E.; Ford, P. C. Chem. Commun. 1999, 1843-1844. (c) Laverman, L. E.; Ford, P. C. J. Am. Chem. Soc. 2001, 123, 11614-11622. 
associative mechanism by which direct $\mathrm{Ru}-\mathrm{NO}$ bond formation assisted release of the normally nonlabile $\mathrm{NH}_{3}$. It would be of interest to establish whether other $\mathrm{Ru}(\mathrm{III})$ complexes react similarly with NO. In this context, photochemical NO labilization from compounds such as I prepares a series of $\mathrm{Ru}(\mathrm{III})$ solvento complexes $\mathrm{Ru}(\mathrm{L})(\mathrm{X})(\mathrm{Sol})$ (Sol = solvent, $\mathrm{L}=\mathrm{R}$-salen or R-salophen) for kinetics studies of this reaction. Described here are detailed kinetics studies of the back-reactions of $\mathrm{Ru}(\mathrm{L})(\mathrm{X})(\mathrm{Sol})$ with excess NO (e.g., eq 3 ) that provide further insight into the mechanism of this substitution reaction.
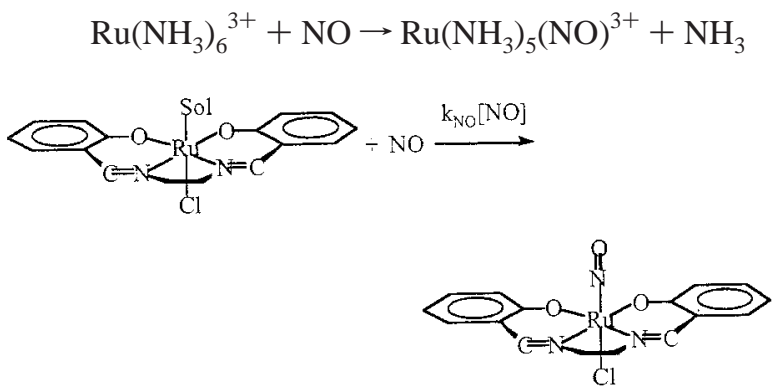

Last, it should further be noted that nitrosyl complexes of ruthenium salen derivatives have also been found to be precursors to oxene and carbene transfer catalysts for asymmetric epoxidations and cyclopropanations of alkenes and of Lewis acid catalysts for asymmetric hetero-DielsAlder reactions. ${ }^{20,21}$ These systems are reportedly activated by light, ${ }^{20}$ so quantitative evaluation of their photochemical properties has relevance beyond the focus on possible biomedical applications.

\section{Experimental Section}

Materials. All solvent distillations were under dinitrogen. Acetonitrile (AN) and cyclohexane were distilled from $\mathrm{CaH}_{2}$, toluene from sodium metal, and tetrahydrofuran (THF) from sodium and benzophenone. Dichloromethane, ethanol, methanol, dimethylformamide (DMF), and diethyl ether were reagent grade and were used as purchased. The 3,5-di-tert-butyl-2-hydroxybenzaldehyde, 3-tert-butyl-2-hydroxybenzaldehyde, 1,2-phenylenediamine, $N, N^{\prime}$ ethylenebis(salicylideneimine), and tetrabutylammonium hexafluorophosphate were bought from Aldrich, ethylenediamine was from Arcos, and $\mathrm{Ru}(\mathrm{NO}) \mathrm{Cl}_{3} \cdot 5 \mathrm{H}_{2} \mathrm{O}$ was from Strem Chemicals. The latter was also prepared from $\mathrm{RuCl}_{3} \cdot 3 \mathrm{H}_{2} \mathrm{O}$ (Johnson-Matthey) according to a published procedure. ${ }^{22}$ The $\mathrm{Ru}($ salen $)\left(\mathrm{PPh}_{3}\right)_{2}$ was prepared according to a literature procedure. ${ }^{23}$ The 1,2-phenylenediamine was recrystallized from ethanol/cold pentane, while the $\left[\mathrm{Bu}_{4} \mathrm{~N}\right]\left[\mathrm{PF}_{6}\right]$ was

(19) (a) Armor, J. N.; Scheidegger, H. A.; Taube, H. J. Am. Chem. Soc. 1968, 90, 5928. (b) Armor, J. N.; Pell, S. D. J. Am. Chem. Soc. 1973, 95,7625 .

(20) (a) Takeda, T.; Irie, R.; Shinoda, Y.; Katsuki, T. Synlett 1999, 07, 1157-1159. (b) Mihara, J.; Hamada, T.; Takede, T.; Irie, R.; Katsuki, T. Synlett 1999, 07, 1160-1162., (c) Uchida, T.; Irie, R.; Katsuki, T. Synlett 1999, 07, 1163-1165. (d) Masutani, K.; Uchida, T.; Irie, R.; Katsuki, T. Tetrahedron Lett. 2000, 41, 5119-5123. (e) Nakata, K.; Takeda, T.; Mihara, J.; Hamada, T.; Irie, R.; Katsuki, T. Chem.-Eur. J. 2001, 7, 3776-3782. (f) Mihara, J.; Aikawa, K.; Uchida, T.; Irie, R.; Katsuki, T. Heterocycles 2001, 54, 395-404.

(21) Odenkirk, W.; Rheingold, A. L.; Bosnich, B. J. Am. Chem. Soc. 1992, 114, 6392-6398.

(22) Muller, J. G.; Takeuchi, J. Inorg. Chem. 1990, 29, 2185-2188.

(23) Carrondo, M. A. A. F. d. C. T.; Skapski, A. C.; Thornback, J. R.; Wilkinson, G. Inorg. Chim. Acta 1977, 24, L95-L96. recrystallized from methanol and stored in a drybox until use. Column chromatography was performed on silica gel (Selecto, particle size 63-200). NO (Matheson, 99.0\%) was passed through an Ascarite II column to remove higher nitrogen oxides.

Syntheses. Syntheses of nitrosyl compounds were performed under argon using standard Schlenk techniques.

Ru(salen)(ONO)(NO) (I, ( $N, N^{\prime}$-Ethylenebis(salicylideneiminato))(nitrito)(nitrosyl)ruthenium). I was prepared by a modification of a published procedure. ${ }^{23} \mathrm{~A}$ solution of $\mathrm{Ru}(\mathrm{salen})\left(\mathrm{PPh}_{3}\right)_{2}(0.50$ $\mathrm{g}, 0.56 \mathrm{mmol})$ in dry deaerated THF was placed into a dropping funnel fitted onto a three-neck $500 \mathrm{~mL}$ round-bottom flask containing $\sim 15 \mathrm{~mL}$ dry, deaerated THF and a magnetic stirring bar. This system was assembled in an inert-atmosphere box and then set up on a vacuum line manifold. Argon was first bubbled through the THF (10 min), and then NO was passed through it. The red $\left[\mathrm{Ru}(\right.$ salen $\left.)\left(\mathrm{PPh}_{3}\right)_{2}\right]$ solution was then added dropwise after which the NO bubbling was stopped, and the reaction mixture was stirred another $10 \mathrm{~min}$. During the addition, the solution turned yellowish green, and some orange solid $\left([\mathrm{Ru}(\mathrm{salen})(\mathrm{NO})]_{2} \mathrm{O}\right)$ deposited on the bottom of the flask (see below). After $10 \mathrm{~min}$ the solution was flushed with argon to remove NO. The solution was filtered under argon to remove the orange precipitate, and the solvent was removed by rotary evaporation. The yellowish residue obtained at this point was washed several times with ether to remove excess $\mathrm{PPh}_{3}$ and then dissolved in $\mathrm{CH}_{2} \mathrm{Cl}_{2}$ and chromatographed on a silica gel column using a $1 \%$ solution of methanol in $\mathrm{CH}_{2} \mathrm{Cl}_{2}$ to elute the products. After solvent evaporation the resulting solid was pentane washed to give a brown powder. The ${ }^{1} \mathrm{H}$ NMR spectrum showed two compounds, so further purification was necessary. Recrystallization either by slow evaporation of a concentrated $\mathrm{CH}_{3} \mathrm{CN}$ solution or by dissolving in minimal $\mathrm{CH}_{2} \mathrm{Cl}_{2}$ and adding pentane dropwise and then refrigerating overnight gave square brown crystals, but yields were not quantified. ${ }^{1} \mathrm{H}$ NMR $\left(\mathrm{CD}_{2} \mathrm{Cl}_{2}\right): \delta 8.31 \mathrm{ppm}(\mathrm{s})$ (methine proton), 7.48-7.43 (t) $(J=$ $7.8 \mathrm{~Hz}), 7.33-7.31(\mathrm{~d})(J=8.0), 7.16-7.13(\mathrm{~d})(J=8.6), 6.76-$ $6.72(\mathrm{t})(J=7.4)$ (aromatic protons), 4.16-4.05 (complex multiplet for the methylene protons) $(J=2.0)$. (The integration is $1: 1: 1: 1: 1$ for the aromatic protons to 1 for the methine protons to 2 for the methylene protons consistent with the molecular symmetry.) $\mathrm{MS}\left(\mathrm{FAB}^{+}\right): \mathrm{m} / \mathrm{z} 398\left(\mathrm{M}-\mathrm{ONO}^{+}\right), 414\left(\mathrm{M}-\mathrm{NO}^{+}\right)$. FTIR $\left(\mathrm{CH}_{3} \mathrm{CN}\right): 1841 \mathrm{~cm}^{-1}\left(\nu_{\mathrm{NO}}\right) ; 1633 \mathrm{~cm}^{-1}\left(\nu_{\mathrm{C}=\mathrm{N}}\right) ; 1603 \mathrm{~cm}^{-1}\left(\nu_{\mathrm{C}=\mathrm{N}}\right)$; $1532 \mathrm{~cm}^{-1}\left(v_{\mathrm{C}=\mathrm{C})}\right)$. UV-vis $\left(\mathrm{CH}_{2} \mathrm{Cl}_{2}\right): \lambda_{\max } 370 \mathrm{~nm}\left(\epsilon 4.6 \times 10^{3}\right.$ $\mathrm{M}^{-1} \mathrm{~cm}^{-1}$ ). An X-ray structure was obtained (see below).

$[\mathbf{R u}(\text { salen })(\mathrm{NO})]_{2} \mathbf{O}$. The oxo-bridged dimer is a byproduct of the synthesis of $\mathbf{I}$. The yield was increased as follows. A concentrated THF solution of $\left[\mathrm{Ru}(\right.$ salen $\left.)\left(\mathrm{PPh}_{3}\right)_{2}\right](0.50 \mathrm{~g}$ in $20 \mathrm{~mL})$ was stirred for $1 \mathrm{~h}$ under excess NO (500 Torr) after which the NO was removed and orange solid was collected by filtration. ${ }^{1} \mathrm{H}$ NMR $\left(\mathrm{CDCl}_{3}\right): 7.76 \mathrm{ppm}$ (methine proton) $(\mathrm{s}), 7.40-7.36(\mathrm{t})(J$ $=7.2 \mathrm{~Hz}), 7.05-7.03$ (d) $(J=8.8), 6.91-6.89$ (d) $(J=7.6)$, $6.602-6.583(\mathrm{t})(J=7.6)$ (aromatic protons) $4.42-4.40$ and $3.93-$ 3.91 (multiplets for methylene protons) $(J=7.8)$. FTIR $\left(\mathrm{CH}_{2} \mathrm{Cl}_{2}\right)$ : $1762 \mathrm{~cm}^{-1}\left(\nu_{\mathrm{NO}}\right) ; 1644,1602,1532 \mathrm{~cm}^{-1}$ (salen bands). $\mathrm{MS}\left(\mathrm{FAB}^{+}\right): m / z, 813\left(\mathrm{M}^{+}\right)$.

$\mathbf{R u}($ salen)(Cl)(NO) (II). This was prepared as described previously $^{21}$ and also by reaction of the dimer with $\mathrm{HCl}$. When $[\mathrm{Ru}(\text { salen })(\mathrm{NO})]_{2} \mathrm{O}(106 \mathrm{mg})$ was dissolved in $\mathrm{CH}_{2} \mathrm{Cl}_{2}(16 \mathrm{~mL})$ and $6 \mathrm{M}$ aqueous $\mathrm{HCl}$ (3 drops) was added, a solid identified as $\left[\mathrm{Ru}(\right.$ salen $\left.)\left(\mathrm{H}_{2} \mathrm{O}\right)(\mathrm{NO})\right] \mathrm{Cl}$ (see below) precipitated from the solution. The precipitate was separated by filtration, and the filtrate solution containing II was evaporated to dryness under reduced pressure. ${ }^{1} \mathrm{H}$ NMR $\left(\mathrm{CDCl}_{3}\right): \delta 8.27 \mathrm{ppm}$ (s) (methine protons), 7.45-7.42 (t) $(J=7.6 \mathrm{~Hz}), 7.33-7.30(\mathrm{~d})(J=8.8), 7.27-7.25(\mathrm{~d})(J=8.8)$, 
6.72-6.68 (t) $(J=7.6)$ (aromatic protons), 4.00 and $4.40(\mathrm{dd})$ (methylene protons). FTIR $\left(\mathrm{CH}_{2} \mathrm{Cl}_{2}\right): 1844 \mathrm{~cm}^{-1}\left(\nu_{\mathrm{NO}}\right) ; 1638 \mathrm{~cm}^{-1}$ $\left(v_{\mathrm{C}=\mathrm{N}}\right) ; 1533 \mathrm{~cm}^{-1}\left(v_{\mathrm{C}=\mathrm{C}}\right)$. UV-vis $\left(\mathrm{CH}_{2} \mathrm{Cl}_{2}\right): 376 \mathrm{~nm}(\epsilon 5.2 \times$ $\left.10^{3} \mathrm{M}^{-1} \mathrm{~cm}^{-1}\right)$.

${ }^{t} \mathrm{Bu}_{4} \mathrm{SalenH}_{2} \quad\left(N, N^{\prime}\right.$-(ethylene)bis(3,5-tert-butylsalicylideneimine)) was prepared by reaction of 3,5-tert-butyl-2-hydroxy benzaldehyde $(1.00 \mathrm{~g}, 5.39 \mathrm{mmol})$ with ethylenediamine $(0.150 \mathrm{~g}$, $2.69 \mathrm{mmol}$ ). The salicyaldehyde was first dissolved in $40 \mathrm{~mL}$ of ethanol, and the solution was heated. To the hot stirring solution, ethylenediamine was added dropwise. The solution was allowed to reflux for $1 \mathrm{~h}$ and then was allowed to cool, and the solids precipitated. These were collected by filtration and found to be pure according to the ${ }^{1} \mathrm{H}$ NMR spectrum. A second crop could be obtained from the liquid by reducing the volume until solids appeared and letting the ethanol slowly evaporate. ${ }^{1} \mathrm{H}$ NMR $\left(\mathrm{CDCl}_{3}\right): \delta 8.43 \mathrm{ppm}(\mathrm{s})$ (methine protons), 7.41 (s), 7.11 (s) (aromatic protons), $3.95(\mathrm{~s})$ (methylene protons), $1.48(\mathrm{~s}), 1.33(\mathrm{~s})$ ( ${ }^{t} \mathrm{Bu}$ protons). $\mathrm{UV}-$ vis (acetonitrile): $330 \mathrm{~nm}\left(\epsilon 8.4 \times 10^{3} \mathrm{M}^{-1}\right.$ $\left.\mathrm{cm}^{-1}\right), 422\left(\epsilon 1.7 \times 10^{2}\right)$.

$\mathbf{R u}\left({ }^{t} \mathbf{B u}_{4}\right.$ salen)(Cl)(NO)) (III). The procedure was similar to that for preparation of II. $\mathrm{RuCl}_{3}(\mathrm{NO}) \cdot 5 \mathrm{H}_{2} \mathrm{O}(0.50 \mathrm{~g} ; 1.97 \mathrm{mmol})$, ${ }^{t} \mathrm{Bu}_{4}$ salen $(0.97 \mathrm{~g}, 1.97 \mathrm{mmol})$, and a stirring bar were placed in a $100 \mathrm{~mL}$ three-neck round-bottom flask with a reflux condenser. The flask was evacuated then flushed with argon 3 times. The solids were left under bubbling argon, and dry, deaerated toluene $(40 \mathrm{~mL})$ was added via cannula. At this point $\mathrm{NEt}_{3}(0.80 \mathrm{~mL} ; 5.91 \mathrm{mmol})$ was added via syringe, and the reaction mixture was heated to reflux for $22 \mathrm{~h}$. The solution was allowed to cool and then was filtered, and the filtrate was collected. The solvent was removed by rotary evaporation. Purification by silica gel chromatography using $\mathrm{CH}_{2} \mathrm{Cl}_{2}$ as the eluent first gave a yellow band collected that was identified as unreacted ligand. The second band was brown and was the compound of interest. The solvent was removed by rotary give a red-brown powder in $88 \%$ yield. ${ }^{1} \mathrm{H} \mathrm{NMR}\left(\mathrm{CDCl}_{3}\right): \delta 8.28(\mathrm{~s})$ (methine proton), 7.57 (d), 7.01 (d) (aromatic protons), 3.89 and 4.38 (dd) (methylene protons), $1.50(\mathrm{~s}), 1.31$ (s) (tert-butyl protons). FTIR $\left(\mathrm{CHCl}_{3}\right): 1831 \mathrm{~cm}^{-1}\left(\nu_{\mathrm{NO}}\right) ; 1625$ and $1602 \mathrm{~cm}^{-1}\left(v_{\mathrm{C}=\mathrm{N}}\right)$; $1525 \mathrm{~cm}^{-1}\left(v_{\mathrm{C}=\mathrm{C}}\right) . \mathrm{UV}-$ vis $\left(\mathrm{CH}_{3} \mathrm{CN}\right): \lambda_{\max } 370 \mathrm{~nm}\left(\epsilon 6.9 \times 10^{3}\right.$ $\left.\mathrm{M}^{-1} \mathrm{~cm}^{-1}\right)$. $\mathrm{MS}\left(\mathrm{FAB}^{+}\right)$: $\mathrm{m} / \mathrm{z} 656\left(\mathrm{M}^{+}\right)$. Anal. Calcd for $\mathrm{C}_{32} \mathrm{H}_{46} \mathrm{O}_{3} \mathrm{~N}_{3^{-}}$ ClRu: C, 58.5; H, 7.0; N. 6.4. Found: C, 57.9, H, 6.8, N, 7.5.

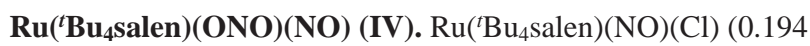
$\mathrm{g}, 0.295 \mathrm{mmol})$ and $\mathrm{AgNO}_{2}(0.091 \mathrm{~g}, 0.295 \mathrm{mmol})$ were placed in a one-neck Schlenk flask with a magnetic stir bar, and the flask was evacuated and filled with argon thrice. The solids were left under flowing argon, and a dry, deaerated 1:1 mixture of $\mathrm{CH}_{3} \mathrm{CN}$ and toluene was added via cannula. The reaction vessel was heated at $40{ }^{\circ} \mathrm{C}$ for $45 \mathrm{~min}$ and then allowed to cool, and the solution was filtered to remove the precipitated $\mathrm{AgCl}$. The solvent was removed by rotary evaporation, and the solid product was redissolved in dichloromethane and chromatographed on silica gel. The first band was yellow and identified as unreacted ligand; the second band was brown and the compound of interest. After collection of the product band, the solvent was removed by rotary evaporation, and a powder was obtained (71\% yield). ${ }^{1} \mathrm{H} \mathrm{NMR}\left(\mathrm{CDCl}_{3}\right): \delta 8.28$ ppm (s) (methine proton), 7.54 (d), 7.02 (d) (aromatic protons), 4.14-4.01 (complex multiplet) (methylene protons), 1.50 (s), 1.31 (s) ( ${ }^{t} \mathrm{Bu}$ protons). FTIR $\left(\mathrm{CH}_{2} \mathrm{Cl}_{2}\right): 1850 \mathrm{~cm}^{-1}\left(\nu_{\mathrm{NO}}\right) ; 1636 \mathrm{~cm}^{-1}$ $\left(v_{\mathrm{C}=\mathrm{N}}\right) ; 1535 \mathrm{~cm}^{-1}\left(v_{\mathrm{C}=\mathrm{C}}\right) . \mathrm{UV}-\mathrm{vis}\left(\mathrm{CH}_{3} \mathrm{CN}\right): \lambda_{\max } 390 \mathrm{~nm}(\epsilon 5.8$ $\left.\times 10^{3} \mathrm{M}^{-1} \mathrm{~cm}^{-1}\right)$.

${ }^{t} \mathbf{B u}_{2}$ SalophenH $\mathrm{H}_{2}\left(\boldsymbol{N}, N^{\prime}\right.$-o-Phenylenebis(3-tert-butylsalicylideneimine)). A mixture of 3-tert-butylsalicylaldehyde (0.78 g, 4.4 $\mathrm{mmol}), o$-phenylenediamine $(0.22 \mathrm{~g}, 2.0 \mathrm{mmol})$, and ethanol $(3 \mathrm{~mL})$ was refluxed for $3 \mathrm{~h}$. The suspension was allowed to cool and sit at room temperature for another $48 \mathrm{~h}$. Yellow orange needles were collected by filtration and dried under reduced pressure for $12 \mathrm{~h}$. Yield: $88 \% .{ }^{1} \mathrm{H} \mathrm{NMR}\left(\mathrm{CDCl}_{3}\right): \delta 13.7 \mathrm{ppm}(\mathrm{s})$, (phenol proton), $8.66(\mathrm{~s})$ (methine proton), $7.39(\mathrm{dd}),\left({ }^{3} J_{\mathrm{HH}}=7.8 \mathrm{~Hz},{ }^{4} J_{\mathrm{HH}}=1.4\right.$ $\mathrm{Hz}), 7.35-7.32(\mathrm{~m}), 7.27-7.24(\mathrm{~m}), 7.24(\mathrm{dd}), 6.86(\mathrm{t})\left({ }^{3} J_{\mathrm{HH}}=\right.$ $7.8 \mathrm{~Hz}$ ) (aromatic protons), $1.58(\mathrm{~s})\left({ }^{t} \mathrm{Bu}\right.$ protons). FTIR $\left(\mathrm{CDCl}_{3}\right)$ : $1612\left(\mathrm{~m}, v_{\mathrm{C}=\mathrm{N}}\right), 1576(\mathrm{w}), 1522(\mathrm{~s}), 1476(\mathrm{~m}), 1424(\mathrm{~s}) \mathrm{cm}^{-1}$. $\mathrm{MS}\left(\mathrm{FAB}^{+}\right): m / z 429\left(\mathrm{M}^{+}\right), 413\left(\mathrm{M}-\mathrm{CH}_{3}{ }^{+}\right), 373\left(\mathrm{M}-{ }^{t} \mathrm{Bu}^{+}\right)$, $267\left(\mathrm{M}-\mathrm{C}_{11} \mathrm{H}_{14} \mathrm{O}^{+}\right)$. UV-vis (acetonitrile): $276 \mathrm{~nm}(\epsilon 2.47 \times$ $\left.10^{4} \mathrm{M}^{-1} \mathrm{~cm}^{-1}\right), 334\left(\epsilon 1.85 \times 10^{4}\right)$.

$\mathbf{R u}\left({ }^{t} \mathbf{B u}_{2}\right.$ salophen $\left.)(\mathbf{C l})\right)(\mathbf{N O})(\mathbf{V})$. To a rapidly stirred suspension of $\mathrm{NaH}(73 \mathrm{mg}, 3.06 \mathrm{mmol})$ in $50 \mathrm{~mL}$ of THF was slowly added ${ }^{t} \mathrm{Bu}_{2}$ salophen $(0.655 \mathrm{~g}, 1.53 \mathrm{mmol})$, and the mixture was stirred until it became a clear solution and the evolution of hydrogen stopped. The solution was refluxed for $0.5 \mathrm{~h}$ before $\mathrm{Ru}(\mathrm{NO}) \mathrm{Cl}_{3}$. $5 \mathrm{H}_{2} \mathrm{O}(0.65 \mathrm{~g}, 2.0 \mathrm{mmol}, 1.3$ equiv) dissolved in $10 \mathrm{~mL}$ of $\mathrm{THF}$ was added dropwise over a period of $1 \mathrm{~h}$. The solution was protected from light and refluxed $30 \mathrm{~h}$. The solvent was then removed by distillation under argon. The crude product was chromatographed on a silica gel column using $\mathrm{CH}_{2} \mathrm{Cl}_{2}$ as eluent. The desired product eluted first $\left(R_{f}=0.6\right)$. (The other products, red in color, adhered to the column but could be removed with methanol (one fraction) and methanol/6 $\mathrm{M} \mathrm{HCl} \mathrm{85/15}$ (second fraction)). The dark red solution of the product band was reduced in volume under reduced pressure, and brown crystals formed. The ${ }^{1} \mathrm{H}$ NMR spectrum showed that $\mathrm{CH}_{2} \mathrm{Cl}_{2}$ remained trapped within the crystals. Under inert atmosphere or reduced pressure, the crystals crumbled into orange-red powder as the solvent was lost. Rinsing the material with pentane removed $\mathrm{CH}_{2} \mathrm{Cl}_{2}$ entirely, and a red brown powder was obtained. Yield: $290 \mathrm{mg}(32 \%)$. FTIR $\left(\mathrm{CDCl}_{3}\right)$ : $1842 \mathrm{~cm}^{-1}$ $\left(v_{\mathrm{NO}}\right) ; 1609 \mathrm{~cm}^{-1}\left(v_{\mathrm{C}=\mathrm{N}}\right) ; 1599 \mathrm{~cm}^{-1}\left(v_{\mathrm{C}=\mathrm{C}}\right)$. FTIR $\left(\mathrm{CH}_{3} \mathrm{CN}\right): 1843$ $\mathrm{cm}^{-1}\left(\nu_{\mathrm{NO}}, \epsilon 1.1 \times 10^{3} \mathrm{M}^{-1} \mathrm{~s}^{-1}\right) ; 1606 \mathrm{~cm}^{-1}\left(\nu_{\mathrm{C}=\mathrm{N}}, \epsilon 1.3 \times 10^{3}\right.$ $\left.\mathrm{M}^{-1} \mathrm{~s}^{-1}\right) .{ }^{1} \mathrm{H}$ NMR $\left(\mathrm{CD}_{2} \mathrm{Cl}_{2}\right): \delta 8.95 \mathrm{ppm}$ (s) (methine protons), $7.98-7.96(\mathrm{~m}), 7.53(\mathrm{dd})\left({ }^{3} J_{\mathrm{HH}}=7.0 \mathrm{~Hz}\right), 7.46-7.44(\mathrm{~m}) 7.36$ (dd) $\left({ }^{3} J_{\mathrm{HH}}=8.1 \mathrm{~Hz}\right), 6.71(\mathrm{t})\left({ }^{3} J_{\mathrm{HH}}=7.7 \mathrm{~Hz}\right)$ (aromatic protons), 1.60 (s) ( ${ }^{t} \mathrm{Bu}$ protons). ${ }^{13} \mathrm{C} \mathrm{NMR}\left(\mathrm{CD}_{2} \mathrm{Cl}_{2}, 125.703 \mathrm{MHz}, 300 \mathrm{~K}\right)$ : $\delta 170.9(C-\mathrm{ORu}), 158.7(\mathrm{~N}=C \mathrm{H}), 143.4(C), 143.3(C), 136.1$ $(\mathrm{CH}), 135.0(\mathrm{CH}), 128.9(\mathrm{CH}), 120.26(\mathrm{CH}), 116.6(\mathrm{CH}), 116.6$ $(\mathrm{CH}), 36.5\left(\mathrm{C}\left(\mathrm{CH}_{3}\right)_{3}\right), 29.9\left(\mathrm{CH}_{3}\right) .{ }^{1} \mathrm{H}-{ }^{13} \mathrm{C}-\mathrm{HETCOR}\left(\mathrm{CD}_{2} \mathrm{Cl}_{2}\right.$, $499.869 \mathrm{MHz} / 125.703 \mathrm{MHz}, 300 \mathrm{~K}): \delta\left({ }^{1} \mathrm{H}\right) / \delta\left({ }^{13} \mathrm{C}\right)=8.95 / 158.7$ $(\mathrm{N}=\mathrm{CH}), 7.97 / 116.6\left(\mathrm{Ar}^{\prime}-\mathrm{CH}\right), 7.53 / 135.0(\mathrm{Ar}-\mathrm{CH}), 7.45 / 128.9$ $\left(\mathrm{Ar}^{\prime}-\mathrm{CH}\right), 7.36 / 136.1(\mathrm{Ar}-\mathrm{CH}), 6.71 / 116.6(5-\mathrm{CH})$. Anal. Calcd for $\mathrm{C}_{28} \mathrm{H}_{30} \mathrm{~N}_{3} \mathrm{O}_{3} \mathrm{ClRu}: \mathrm{C}, 55.3 ; \mathrm{H}, 5.0 ; \mathrm{N}, 7.2 ; \mathrm{Cl}, 5.69$. Found: $\mathrm{C}$, 56.7; H, 5.1; N, 7.1; Cl, 6.0. MS(FAB): $m / z 593\left(\mathrm{M}^{+}\right), 558(\mathrm{M}-$ $\left.\mathrm{Cl}^{+}\right), 528\left(\mathrm{M}-\mathrm{Cl}-\mathrm{NO}^{+}\right)$. UV-vis $\left(\mathrm{CH}_{3} \mathrm{CN}\right): 458 \mathrm{~nm}(\epsilon 1.03$ $\left.\times 10^{4} \mathrm{~cm}^{-1} \mathrm{M}^{-1}\right)$. UV-vis (THF): $466 \mathrm{~nm}\left(\epsilon=1.33 \times 10^{-4}\right.$ $\left.\mathrm{cm}^{-1} \mathrm{M}^{-1}\right)$. UV-vis $\left(\mathrm{CH}_{3} \mathrm{OH}\right): 458 \mathrm{~nm}\left(\epsilon=1.12 \times 10^{4} \mathrm{~cm}^{-1} \mathrm{M}^{-1}\right)$.

${ }^{t} \mathbf{B u}_{4}$ SalophenH $H_{2}\left(N, N^{\prime}\right.$-o-phenylenebis(3,5-di-tert-butylsalicylideneimine)) was prepared by a literature procedure. ${ }^{24}$ A $2: 1$ (stoichiometric) solution of the aldehyde and $o$-phenylenediamine in ethanol was refluxed for several hours. The mixture was allowed to cool and to sit at room temperature for several days before filtering to collect the solid product. ${ }^{1} \mathrm{H}$ NMR $\left(\mathrm{CDCl}_{3}\right): \delta 13.74$ (s) (phenol proton), 8.67 (s) (methine protons), 7.39 (dd) $\left({ }^{3} \mathrm{~J}=7.8\right.$ $\mathrm{Hz}), 7.36-7.32(\mathrm{~m}), 7.25(\mathrm{dd})\left({ }^{3} J=7.8 \mathrm{~Hz}\right), 7.27-7.23(\mathrm{~m}), 6.86$ (t) $\left({ }^{3} J=7.6 \mathrm{~Hz}\right)$ (aromatic protons), $1.44(\mathrm{~s})\left({ }^{t} \mathrm{Bu}\right.$ protons). FTIR $\left(\mathrm{CDCl}_{3}\right): 1615 \mathrm{~cm}^{-1}\left(v_{\mathrm{C}=\mathrm{N}}\right) \cdot \mathrm{MS}\left(\mathrm{FAB}^{+}\right): m / z 541\left(\mathrm{M}^{+}\right), 525(\mathrm{M}$ $\left.-\mathrm{CH}_{3}{ }^{+}\right), 485\left(\mathrm{M}-\mathrm{C}\left(\mathrm{CH}_{3}\right)_{3}{ }^{+}\right)$. UV-vis (THF): $340 \mathrm{~nm}(\epsilon 1.92$ $\left.\times 10^{4} \mathrm{M}^{-1} \mathrm{~cm}^{-1}\right)$. UV-vis $\left(\mathrm{CH}_{3} \mathrm{CN}\right): 280\left(\epsilon 2.7 \times 10^{4} \mathrm{M}^{-1} \mathrm{~cm}^{-1}\right)$, $336 \mathrm{~nm}\left(\epsilon 1.91 \times 10^{4}\right)$.

(24) (a) Pfeiffer, P. T. H. J. Prakt. Chem. 1937, 149, 242-275. (b) Woltinger, J.; Backvall, J. E.; Zsigmond, A. Chem.-Eur. J. 1999, 5, 1460-1467. 
$\mathbf{R u}\left({ }^{t} \mathbf{B u}_{4}\right.$ salophen)(CI)(NO) (VI). In an inert-atmosphere box, ${ }^{t} \mathrm{Bu}_{4}$ salophen $(0.43 \mathrm{~g}, 0.8 \mathrm{mmol})$ was added to a rapidly stirred $\mathrm{NaH}$ suspension (38 mg, $1.6 \mathrm{mmol}$ ) in $10 \mathrm{~mL}$ of $\mathrm{DMF}$, and the mixture was stirred until $\mathrm{H}_{2}$ evolution ceased and a clear red solution formed $(1 \mathrm{~h})$. This was heated to $105^{\circ} \mathrm{C}$ under argon, and $\mathrm{RuCl}_{3}$ $(\mathrm{NO}) \cdot 5 \mathrm{H}_{2} \mathrm{O}(0.260 \mathrm{~g}, 0.8 \mathrm{mmol})$ dissolved in $10 \mathrm{~mL}$ of DMF was added dropwise over a period of $2 \mathrm{~h}$. The solution was protected from light and kept at $105^{\circ} \mathrm{C}$ for $22 \mathrm{~h}$ after which the DMF was partly removed under reduced pressure. A mixture of $90 \mathrm{~mL}$ of water and $80 \mathrm{~mL}$ of $\mathrm{CH}_{2} \mathrm{Cl}_{2}$ was then added to this residue. The organic phase was separated, washed 3 times with $80 \mathrm{~mL}$ of water, and then dried by stirring over $8 \mathrm{~g}$ of $\mathrm{MgSO}_{4}$ for $4 \mathrm{~min}$. The solution was filtrated, and the volume of the filtrate was reduced under vacuum. Afterward, the solution was dried again by stirring over 8 $\mathrm{g}$ of $\mathrm{MgSO}_{4}$ for $10 \mathrm{~min}$. Ether diffusion into this solution over 14 days led to a mixture of dark red crystals and black powder. The crude product was dissolved in $\mathrm{CH}_{2} \mathrm{Cl}_{2}$ and added to a dry packed silica column. After the $\mathrm{CH}_{2} \mathrm{Cl}_{2}$ evaporated, the column was rinsed with pentane and 85:15 pentane/ether $(\mathrm{v} / \mathrm{v})$ to remove the ligand. The eluent was then changed to $\mathrm{CH}_{2} \mathrm{Cl}_{2}$ and pure product eluted from the column. (In addition, an uncharacterized green band eluted with $\mathrm{CH}_{2} \mathrm{Cl}_{2}$ while a red band characterized to be the $\mu$-oxo dimer eluted with methanol. Last, a reddish orange band eluted with a methanol/6 $\mathrm{M} \mathrm{HCl}(85: 15 \mathrm{v} / \mathrm{v})$ mixture. $){ }^{1} \mathrm{H} \mathrm{NMR}\left(\mathrm{CDCl}_{3}\right): \delta 8.91$ (s) (methine protons), 7.97-7.92 (m), $7.6(\mathrm{~d})\left({ }^{4} J_{\mathrm{HH}}=2.4 \mathrm{~Hz}\right)$, $7.41-7.36(\mathrm{~m}), 7.19(\mathrm{~d})\left({ }^{4} J_{\mathrm{HH}}=2.4 \mathrm{~Hz}\right)$ (aromatic protons), 1.60 (s) and 1.36 (s) ( ${ }^{t} \mathrm{Bu}$ protons). FTIR $\left(\mathrm{CDCl}_{3}\right): 1843 \mathrm{~cm}^{-1}\left(\nu_{\mathrm{NO}}, \epsilon\right.$ $\left.=1.1 \times 10^{4} \mathrm{M}^{-1} \mathrm{~cm}^{-1}\right) ; 1606 \mathrm{~cm}^{-1}\left(\nu_{\mathrm{C}=\mathrm{N}}, \epsilon=1.3 \times 10^{4} \mathrm{M}^{-1}\right.$ $\left.\mathrm{cm}^{-1}\right) \cdot \operatorname{MS}\left(\mathrm{FAB}^{+}\right): \mathrm{m} / \mathrm{z} 705\left(\mathrm{M}^{+}\right), 688,675\left(\mathrm{M}-\mathrm{NO}^{+}\right), 670(\mathrm{M}$ $\left.-\mathrm{Cl}^{+}\right)$. UV-vis $\left(\mathrm{CH}_{3} \mathrm{CN}\right): 468 \mathrm{~nm}\left(1.11 \times 10^{4} \mathrm{M}^{-1} \mathrm{~cm}^{-1}\right)$. A crystal structure was determined for VI (see below).

$\left[\mathbf{R u}(\right.$ salen $\left.)\left(\mathbf{H}_{2} \mathbf{O}\right)(\mathbf{N O})\right] \mathbf{C l}$ (VII). This was the second product in the synthesis of II from the dimer. To increase the yield of VII over that of II, the amount of water can be increased. ${ }^{1} \mathrm{H}$ NMR $\left(\mathrm{C}_{3} \mathrm{D}_{6} \mathrm{O}\right): \delta 8.14(\mathrm{~s})$ (methine protons), $7.40(\mathrm{t}), 7.07(\mathrm{~d}), 7.04(\mathrm{~d})$, $6.64(\mathrm{t})$ (aromatic protons), 4.54 and 4.15 (complex multiplet) (methylene protons). FTIR (acetone): $1856 \mathrm{~cm}^{-1}\left(\nu_{\mathrm{NO}}\right) ; 1644$ and $1603 \mathrm{~cm}^{-1}\left(v_{\mathrm{C}=\mathrm{N}}\right)$. UV-vis $\left(\mathrm{H}_{2} \mathrm{O}\right): 354 \mathrm{~nm}\left(3.8 \times 10^{3} \mathrm{M}^{-1} \mathrm{~cm}^{-1}\right)$.

Instrumentation and Techniques. Optical spectra were recorded on a HP-8452A diode array spectrophotometer and FTIR spectra on a Bio-Rad FTS-60 spectrophotometer. NMR spectra were obtained on a Varian 400 or $500 \mathrm{MHz}$ nuclear magnetic resonance spectrometer. FAB mass spectra were obtained on VG 70E double focusing mass spectrometer.

Laser Flash Photolysis Instrumentation. Time-resolved optical (TRO) spectra were recorded on flash photolysis systems described previously. ${ }^{25}$ One employed a RCA 8852 phototmultiplier tube (PMT) detector to record kinetic traces by single-wavelength detection. The other used a Princeton Instruments model 1024EUV CCD camera to record transient spectra. The pump source was the third harmonic (355 nm) output of a Continuum NY-61 Nd:YAG pulsed laser. The photolysis cell was mounted in a regulated constant temperature cell holder. Hydrostatic pressure studies were carried out using a high-pressure system with a "pillbox" cell as described elsewhere. ${ }^{26}$

Solution Preparations. Solutions for kinetics and photolysis studies were prepared from dried and distilled solvents in an argonfilled VAC inert-atmosphere box. Optical densities were $\sim 0.6$ at

(25) Bridgewater, J. S.; Netzel, T. L.; Schoonover, J. R.; Massick, S. M.; Ford, P. C. Inorg. Chem. 2001, 40, 1466-1476

(26) (a) van Eldik, R.; Ford, P. C. Adv. Photochem. 1998, 24, 61-146. (b) Crane, D. R.; Ford, P. C. J. Am. Chem. Soc. 1991, 113, 8510-8516. (c) Traylor, T. G.; Luo, J.; Simon; J. A.; Ford, P. C. J. Am. Chem. Soc. 1992, 114, 4340-4345. the monitoring wavelength. Flash photolysis solutions were deaerated by freeze-pump-thaw cycles in a cell with a four-sided quartz cuvette and adapted for connection to a gas/vacuum manifold. After degassing, samples were equilibrated with a barometric measured PNO (corrected for solvent vapor pressure). Alternatively a known quantity of $\mathrm{NO}$ was frozen into a cell. The NO concentrations were calculated from the $P_{\mathrm{NO}}$ and the solubility of NO in the appropriate solvent. ${ }^{27}$ For laser flash experiments, absorption spectra of photolysis solutions were recorded before and after to evaluate any sample decomposition.

Back-Reaction Kinetics. Slower reaction rates were determined using a HP-8452A diode array spectrophotometer and HP kinetic software. The magnetically stirred samples were first subjected to continuous photolysis from a $200 \mathrm{~W}$ high-pressure $\mathrm{Hg}$ lamp using band-pass filters to select the irradiation wavelength $\left(\lambda_{\text {irr }}\right)$. Once the photochemical reaction was near completion, spectral changes due to the back-reaction were followed at a regulated constant temperature.

Quantum Yield Measurements. Chemical actinometry was performed with ferric oxalate solutions. ${ }^{28}$ The photolysis source was the output from a $200 \mathrm{~W}$ high-pressure mercury lamp passed through an IR filter and collimated with lenses. An appropriate interference filter was used to select the desired $\lambda_{\text {irr }}$. A shutter shielded the sample from the arc lamp. A sample of known volume in a quartz $1 \mathrm{~cm}$ square cuvette with a magnetic stirring bar was irradiated for defined time periods. The UV-vis spectrum of the sample was recorded after each irradiation period, and this process was repeated until approximately $30 \%$ of the reaction was completed.

Data Analysis. Intensity vs time traces obtained in the laser flash photolysis experiments were converted to $\Delta \mathrm{Abs}$ vs time plots by use of either Scopemate (a custom program) or Igor (Wavemetrics) software. Curve fitting for exponential $\Delta \mathrm{Abs}$ vs time and Abs vs time traces was accomplished using Igor software. Second-order rate constants $k_{\mathrm{NO}}$ were determined by plotting $k_{\mathrm{obs}} \mathrm{vs}$ [NO] and fitting the result to a linear equation.

Quantum yields were determined by fitting a plot of incremented quantum yields (first 10-30\% of the reaction) for each absorbance change vs percent reaction, with a linear equation. The $y$ intercept is the quantum yield. All reported numbers are the average of 3 independent experiments, and the error is the standard deviation.

Crystal Structures. Room-temperature single-crystal studies were carried out on a Siemens Smart CCD diffractometer equipped with normal-focus $2.4 \mathrm{~kW}$ sealed-tube X-ray source (Mo $\mathrm{K} \alpha$ radiation) operating at $50 \mathrm{kV}$ and $40 \mathrm{~mA}$ with a two-dimensional $\mathrm{CCD}$ detector. Computations were performed on a Silicon Graphics Indy 5000. The crystals were solved by direct methods followed by difference Fourier methods.

\section{Results and Discussion}

Syntheses. The salophen complexes V and VI were prepared by the steps described by Scheme 1. The salen complexes II-IV could be prepared by an analogous procedure using ethylenediamine rather than the phenylenediamine in the first step. The synthesis of Ru(salen)(ONO)(NO) (I) was also accomplished from the reaction of excess $\mathrm{NO}$ with $\mathrm{Ru}($ salen $)\left(\mathrm{PPh}_{3}\right)_{2}$ as described earlier; however, this procedure led to copious quantities of the insoluble dimer

(27) “Oxides of Nitrogen”, IUAPC Solubility Data Series, Vol. 8; Young, C. L, Ed.; Pergamon Press: Oxford, U.K., 1983.

(28) (a) Calvert, J. G.; Pitts, J. N. Photochemistry; J. Wiley \& Sons: New York, 1967; pp 783-786. (b) Malouf, G.; Ford, P. C. J. Am. Chem. Soc. 1977, 99, 7213-7221. 
Scheme 1. Synthesis of Ru(R-Salophen $)(\mathrm{X})(\mathrm{NO})$
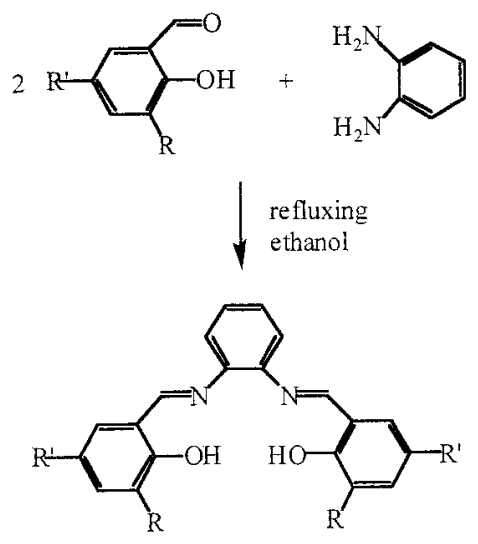

$\begin{cases}\text { 1. } & 2 \mathrm{NaH} \\ \text { 2. } & \mathrm{Ru}(\mathrm{NO}) \mathrm{Cl}_{3}\end{cases}$

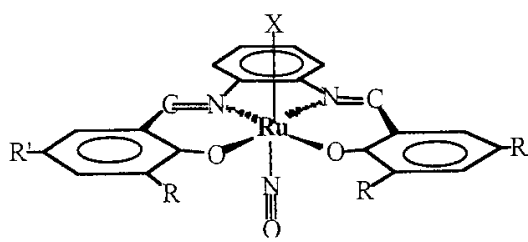

Table 1. Crystal Data and Structure Refinement for $\mathrm{Ru}($ salen$)(\mathrm{ONO})(\mathrm{NO})(\mathbf{I})$

\begin{tabular}{ll}
\hline empirical formula & $\mathrm{C}_{16} \mathrm{H}_{14} \mathrm{~N}_{4} \mathrm{O}_{5} \mathrm{Ru}$ \\
fw & 443.38 \\
temp & $293(2) \mathrm{K}$ \\
wavelength & $0.71073 \AA$ \\
cryst system & monoclinic \\
space group & $P 2_{1} / c$ \\
unit cell dimens & $a=21.4680(5) \AA, \alpha=90^{\circ}$, \\
& $b=13.12060(10) \AA, \beta=92.1510(10)^{\circ}$, \\
& $c=12.0083(3) \AA, \gamma=90^{\circ}$ \\
$V, Z$ & $3380.03(12) \AA^{3}, 8$ \\
density (calcd) & $1.743 \mathrm{Mg} / \mathrm{m}^{3}$ \\
abs coeff & $0.964 \mathrm{~mm}{ }^{-1}$ \\
$F(000)$ & 1776 \\
cryst size & $0.13 \times 0.11 \times 0.027 \mathrm{~mm}$ \\
$\theta$ range for data collcn & $1.82-24.00^{\circ}$ \\
limiting indices & $28 \leq h \leq 28,14 \leq k \leq 17,13 \leq l \leq 15$ \\
reflcns collcd & 14816 \\
indepdt reflcns & $5231[\mathrm{R}(\mathrm{int})=0.1002]$ \\
refinement method & full-matrix least-squares on $F^{2}$ \\
data/restraints/params & $5231 / 0 / 469$ \\
goodness-of-fit on $F^{2}$ & 0.992 \\
final R indices $[I>2 \sigma(I)]$ & $\mathrm{R} 1=0.0599, \mathrm{wR} 2=0.0739$ \\
$\mathrm{R}$ indices (all data) & $\mathrm{R} 1=0.1239, \mathrm{wR} 2=0.0874$ \\
largest diff peak and hole & 0.565 and $0.539 \mathrm{e} \AA$ \\
&
\end{tabular}

$[\mathrm{Ru}(\text { salen })(\mathrm{NO})]_{2} \mathrm{O}$ unless the ruthenium precursor was added to the reaction very slowly. The dimer did prove to be a suitable precursor to the water soluble salt $\left[\mathrm{Ru}(\right.$ salen $)\left(\mathrm{H}_{2} \mathrm{O}\right)$ $(\mathrm{NO})] \mathrm{Cl}$, which was formed upon hydrolysis of the dimer in dilute aqueous $\mathrm{HCl}$.

Crystal Structures. Ru(salen)(ONO)(NO) (I). Wilkinson et al. reported in 1977 the synthesis of $\mathbf{I}$ and some aspects of the structure. ${ }^{23}$ Reported here are the full details of a newly determined crystal structure. A crystal grown by slow evaporation from acetonitrile solution was mounted on a thin glass fiber with epoxy resin. Unit cell dimensions were determined by a least-squares fit of reflections with $I>$ $10 \sigma(I)$ and $10^{\circ}<2 \theta<56^{\circ}$. The number of reflections used in the cell refinement was 14816 . The empirical absorption
Table 2. Selected Bond Lengths ( $\mathrm{A})$ and Bond Angles (deg) for $\mathrm{Ru}($ salen)(ONO)(NO) (I)

\begin{tabular}{lclr}
\hline $\mathrm{Ru}(1)-\mathrm{N}(3)$ & $1.746(6)$ & $\mathrm{Ru}(2)-\mathrm{N}(7)$ & $1.743(6)$ \\
$\mathrm{Ru}(1)-\mathrm{N}(1)$ & $1.998(6)$ & $\mathrm{Ru}(2)-\mathrm{N}(6)$ & $2.014(5)$ \\
$\mathrm{Ru}(1)-\mathrm{N}(2)$ & $2.021(5)$ & $\mathrm{Ru}(2)-\mathrm{N}(5)$ & $2.016(5)$ \\
$\mathrm{Ru}(1)-\mathrm{O}(12)$ & $2.035(5)$ & $\mathrm{Ru}(2)-\mathrm{O}(24)$ & $2.025(6)$ \\
$\mathrm{Ru}(1)-\mathrm{O}(14)$ & $2.039(5)$ & $\mathrm{Ru}(2)-\mathrm{O}(21)$ & $2.030(4)$ \\
$\mathrm{Ru}(1)-\mathrm{O}(11)$ & $2.040(4)$ & $\mathrm{Ru}(2)-\mathrm{O}(22)$ & $2.041(4)$ \\
$\mathrm{O}(13)-\mathrm{N}(3)$ & $1.138(6)$ & $\mathrm{O}(23)-\mathrm{N}(7)$ & $1.138(6)$ \\
$\mathrm{O}(14)-\mathrm{N}(4)$ & $1.205(8)$ & $\mathrm{O}(24)-\mathrm{N}(8)$ & $1.099(8)$ \\
$\mathrm{O}(15)-\mathrm{N}(4)$ & $1.172(8)$ & $\mathrm{O}(25)-\mathrm{N}(8)$ & $1.208(9)$ \\
$\mathrm{N}(1)-\mathrm{Ru}(1)-\mathrm{N}(2)$ & $82.1(2)$ & $\mathrm{N}(6)-\mathrm{Ru}(2)-\mathrm{N}(5)$ & $82.6(2)$ \\
$\mathrm{N}(2)-\mathrm{Ru}(1)-\mathrm{O}(12)$ & $94.0(2)$ & $\mathrm{N}(5)-\mathrm{Ru}(2)-\mathrm{O}(21)$ & $94.0(2)$ \\
$\mathrm{N}(3)-\mathrm{Ru}(1)-\mathrm{O}(14)$ & $175.0(2)$ & $\mathrm{N}(7)-\mathrm{Ru}(2)-\mathrm{O}(24)$ & $176.6(2)$ \\
$\mathrm{N}(1)-\mathrm{Ru}(1)-\mathrm{O}(11)$ & $94.4(2)$ & $\mathrm{N}(6)-\mathrm{Ru}(2)-\mathrm{O}(22)$ & $93.6(2)$ \\
$\mathrm{O}(12)-\mathrm{Ru}(1)-\mathrm{O}(11)$ & $88.1(2)$ & $\mathrm{O}(21)-\mathrm{Ru}(2)-\mathrm{O}(22)$ & $88.7(2)$ \\
$\mathrm{N}(4)-\mathrm{O}(14)-\mathrm{Ru}(1)$ & $120.5(5)$ & $\mathrm{N}(8)-\mathrm{O}(24)-\mathrm{Ru}(2)$ & $127.5(7)$ \\
$\mathrm{O}(13)-\mathrm{N}(3)-\mathrm{Ru}(1)$ & $176.4(6)$ & $\mathrm{O}(23)-\mathrm{N}(7)-\mathrm{Ru}(2)$ & $175.9(6)$ \\
$\mathrm{O}(15)-\mathrm{N}(4)-\mathrm{O}(14)$ & $118.6(9$ & $\mathrm{O}(24)-\mathrm{N}(8)-\mathrm{O}(25)$ & $122.9(10)$
\end{tabular}

Table 3. Crystal Data and Structure Refinement for $\mathrm{Ru}\left({ }^{t} \mathrm{Bu}_{2}\right.$ Salophen $)(\mathrm{Cl})(\mathrm{NO})(\mathbf{V})$

\begin{tabular}{ll}
\hline empirical formula & $\mathrm{C}_{28} \mathrm{H}_{30} \mathrm{ClN}_{3} \mathrm{O}_{3} \mathrm{Ru}$ \\
fw & 593.07 \\
temp & $293(2) \mathrm{K}$ \\
wavelength & $0.71073 \AA$ \\
cryst system & triclinic \\
space group & $P \overline{1}$ \\
unit cell dimens & $a=6.7817(4) \AA, \alpha=81.2400(10)^{\circ}$, \\
& $b=14.1412(7) \AA, \beta=79.5850(10)^{\circ}$, \\
& $c=14.6124(8) \AA, \gamma=89.7130(10)^{\circ}$ \\
$V, Z$ & $1361.82(13) \AA^{3}, 2$ \\
density (calcd) & $1.446 \mathrm{Mg} / \mathrm{m}^{3}$ \\
abs coeff & $0.707 \mathrm{~mm}-1$ \\
$F(000)$ & 608 \\
cryst size & $0.52 \times 0.26 \times 0.13 \mathrm{~mm}$ \\
$\theta$ range for data collcn & $1.88-28.00^{\circ}$ \\
limiting indices & $8 \leq h \leq 8,18 \leq k \leq 18,18 \leq l \leq 18$ \\
reflcns collcd & 14136 \\
indepdt reflcns & $6081[\mathrm{R}(\mathrm{int})=0.0323]$ \\
refinement method & full-matrix least-squares on $F^{2}$ \\
data/restraints/params & $6081 / 0 / 331$ \\
goodness-of-fit on $F^{2}$ & 0.862 \\
final R indices $[I>2 \sigma(I)]$ & $\mathrm{R} 1=0.0273, \mathrm{wR} 2=0.0572$ \\
$\mathrm{R}$ indices (all data) & $\mathrm{R} 1=0.0363, \mathrm{wR} 2=0.0582$ \\
largest diff peak and hole & 0.371 and $0.554 \mathrm{e} \AA^{-3}$ \\
& \\
&
\end{tabular}

correction was based on the symmetry equivalent reflections, and other possible effects and other possible effects such as crystal decay and absorption by the glass fiber were simultaneously corrected. The structure was determined with an $R_{f}$ factor of 0.0599 . Detailed crystal data for $\mathbf{I}$ are listed in Table 1.

The asymmetric unit of $\mathbf{I}$ consists of two independent molecules. The NO is bound to the metal in a nearly linear fashion for both molecules with bond angles of $176.4^{\circ}$ for $\mathrm{O}-\mathrm{N}-\mathrm{Ru}(1)$ and $175.9^{\circ}$ for $\mathrm{O}-\mathrm{N}-\mathrm{Ru}(2)$. The nitrite $\mathrm{ONO}$ angle is $118.6^{\circ}$ in structure 1 and $122.9^{\circ}$ in structure 2 . Selected bond lengths and angles are listed in Table 2, and the complete data are given in the Supporting Information.

$\mathbf{R u}\left({ }^{t} \mathbf{B u}_{2}\right.$ salophen)(Cl)(NO) (V). A suitable crystal of $\mathbf{V}$ grown by slow evaporation of a toluene solution was mounted on a thin glass fiber with epoxy resin. Unit cell dimensions were determined by a least-squares fit of reflections with $I>10 \sigma(I)$ and $4^{\circ}<2 \theta<56^{\circ}$. The number of reflections used in the cell refinement was 14316 . The empirical absorption correction was based on the symmetry equivalent reflections; other possible effects such as crystal decay and absorption by the glass fiber were simultaneously 


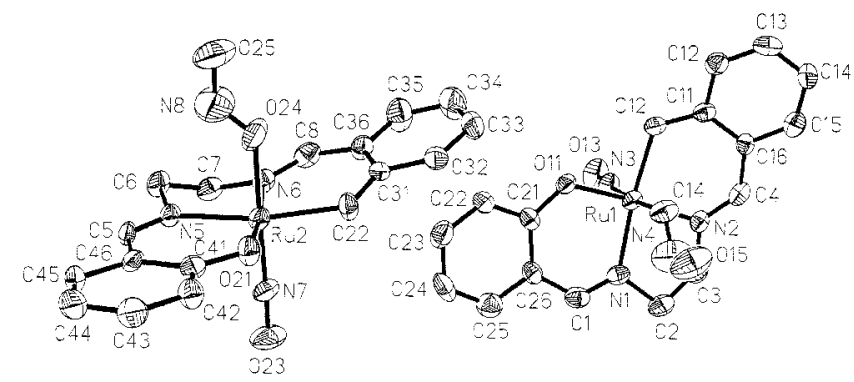

Figure 2. Molecular structures and atom labels for $\mathrm{Ru}(\mathrm{salen})(\mathrm{ONO})(\mathrm{NO})$ as determined by X-ray crystallography.

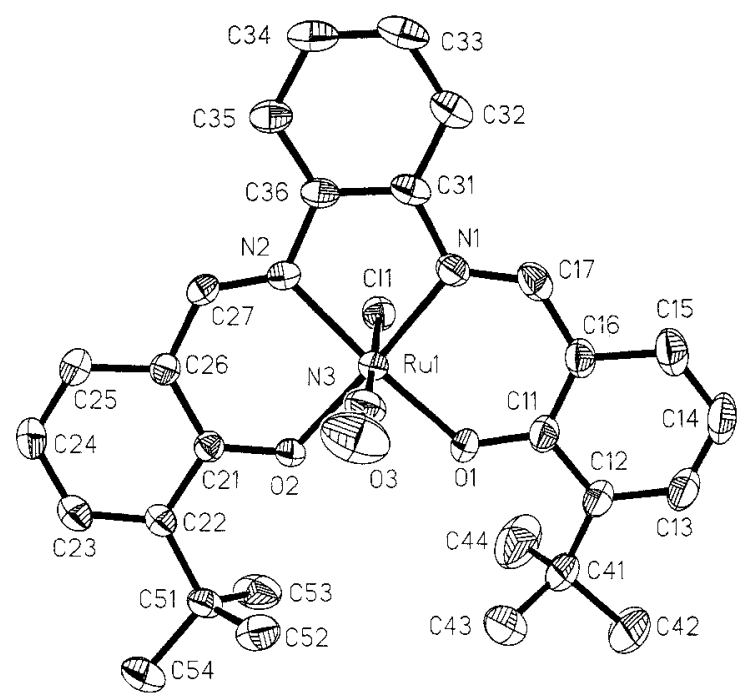

Figure 3. Side-on view of the molecular structure of $\mathrm{Ru}\left({ }^{t} \mathrm{Bu}_{2}\right.$ salophen)$(\mathrm{Cl})(\mathrm{NO})$.

Table 4. Selected Bond Lengths ( $\AA$ ) and Angles (deg) for $\mathrm{Ru}\left({ }^{t} \mathrm{Bu}_{2} \mathrm{Salophen}\right)(\mathrm{Cl})(\mathrm{NO})(\mathbf{V})$

\begin{tabular}{llll}
\hline $\mathrm{Ru}(1)-\mathrm{N}(3)$ & $1.723(2)$ & $\mathrm{Ru}(1)-\mathrm{N}(1)$ & $2.009(2)$ \\
$\mathrm{Ru}(1)-\mathrm{N}(2)$ & $2.013(2)$ & $\mathrm{Ru}(1)-\mathrm{O}(1)$ & $2.0197(14)$ \\
$\mathrm{Ru}(1)-\mathrm{O}(2)$ & $2.0254(13)$ & $\mathrm{Ru}(1)-\mathrm{Cl}(1)$ & $2.3669(6)$ \\
$\mathrm{N}(3)-\mathrm{O}(3)$ & $1.135(2)$ & & \\
$\mathrm{N}(1)-\mathrm{Ru}(1)-\mathrm{N}(2)$ & $82.62(7)$ & $\mathrm{N}(1)-\mathrm{Ru}(1)-\mathrm{O}(1)$ & $94.16(7)$ \\
$\mathrm{N}(2)-\mathrm{Ru}(1)-\mathrm{O}(2)$ & $94.17(6)$ & $\mathrm{O}(1)-\mathrm{Ru}(1)-\mathrm{O}(2)$ & $88.50(6)$ \\
$\mathrm{N}(2)-\mathrm{Ru}(1)-\mathrm{O}(1)$ & $172.32(7)$ & $\mathrm{N}(1)-\mathrm{Ru}(1)-\mathrm{O}(2)$ & $174.69(7)$ \\
$\mathrm{N}(3)-\mathrm{Ru}(1)-\mathrm{Cl}(1)$ & $178.20(7)$ & $\mathrm{O}(3)-\mathrm{N}(3)-\mathrm{Ru}(1)$ & $176.5(2)$
\end{tabular}

corrected. The X-ray crystal structure was determined with an $R_{f}$ factor of 0.0273 . Detailed crystal data are listed in Table 3 .

The asymmetric unit of $\mathbf{V}$ consists of only one molecule, the structure of which is shown in Figure 3. The $\mathrm{Ru}-\mathrm{NO}$ bond is approximately linear with a bond angle of $176.5^{\circ}$ and a $\mathrm{Ru}-\mathrm{N}$ bond length of $1.723 \AA$. Selected bond lengths and angles are shown in Table 4, and complete data are given in the Supporting Information.

The nearly linear $\mathrm{Ru}-\mathrm{N}-\mathrm{O}$ bond angles found for $\mathbf{I}$ (Figure 2, 176.4 and $175.9^{\circ}$ ) and for $\mathbf{V}$ (Figure 3, 176.5 $)$ are in accord with expectations for the $\left\{\mathrm{RuNO}^{6}{ }^{6}\right.$ electronic configuration. ${ }^{29}$ Formally, these species can be represented as $\mathrm{Ru}^{\mathrm{II}}\left(\mathrm{NO}^{+}\right)$complexes, consistent with their diamagnetic natures (sharp ${ }^{1} \mathrm{H}$ NMR spectra were obtained) and their relatively high frequency $v_{\mathrm{NO}}$ bands, $1841 \mathrm{~cm}^{-1}$ for $\mathbf{I}$ and $1843 \mathrm{~cm}^{-1}$ for $\mathbf{V}$ in acetonitrile. The $\mathrm{Ru}-\mathrm{N}-\mathrm{O}$ angles found

(29) Enemark, J. H.; Feltham, R. D. J. Am. Chem. Soc. 1974, 96, 50025004.

3734 Inorganic Chemistry, Vol. 41, No. 14, 2002

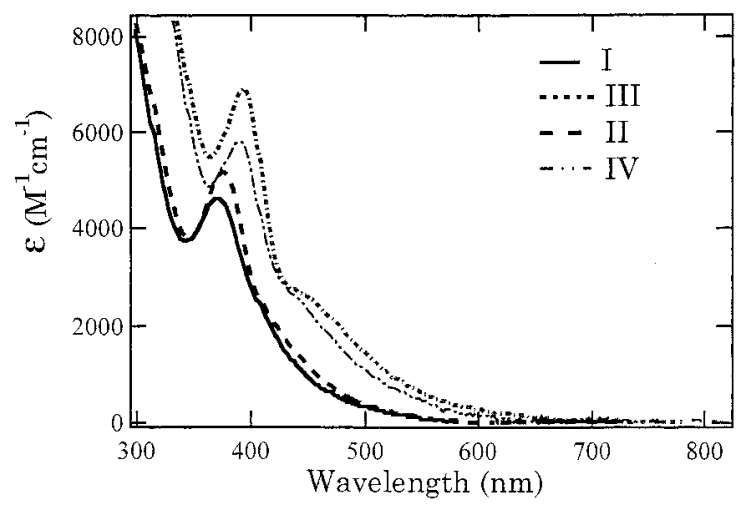

Figure 4. Electronic spectra of compounds $\mathbf{I}-\mathbf{I V}$ in acetonitrile solution.

for the analogous porphyrin complexes $\mathrm{Ru}(\mathrm{TPP})(\mathrm{ONO})(\mathrm{NO})$ and $\mathrm{Ru}(\mathrm{OEP})(\mathrm{ONO})(\mathrm{NO})(\mathrm{TPP}=$ tetraphenylporphyrniato, $\mathrm{OEP}=$ octaethylporphyrinato) were 180.0 and $174.0^{\circ}$, and the $v_{\mathrm{NO}}$ bands in $\mathrm{CH}_{2} \mathrm{Cl}_{2}$ occur at 1860 and $1851 \mathrm{~cm}^{-1}$, respectively. ${ }^{7 a}$ Notably, for all of these complexes the $\mathrm{NO}_{2}{ }^{-}$ anion is oxygen coordinated; i.e., these are "nitrito" rather than "nitro" complexes.

A comparison of molecular packing modes in $\mathbf{I}$ and $\mathbf{V}$ (Supporting Information Figures S-1 and S-2) reveals an interesting steric effect of the tert-butyl on the intermolecular interactions and on molecular packing modes. In $\mathbf{I}$ the two molecules in the asymmetric unit are oriented with a $85.7^{\circ}$ angle between two molecular planes defined by organic ligands. The intermolecular packing force appears to be hydrogen bonding between the phenoxy oxygen of one molecule and $\mathrm{C}-\mathrm{H}$ groups of adjacent molecules. These $\mathrm{C}-\mathrm{H} \cdots \mathrm{O}$ interactions are evidenced by short $\mathrm{O} \cdots \mathrm{H}$ distances of 2.37 and $2.53 \AA$ (on the basis of calculated hydrogen positions). In comparison, the shortest $\mathrm{O} \cdots \mathrm{H}$ distances involving the $\mathrm{NO}$ and $\mathrm{ONO}$ groups are $>2.7 \AA$. For $\mathbf{V}$ the tert-butyl groups of shield the phenoxy oxygens from such interactions. The plane defined by the salophen ligand is tilted about $32^{\circ}$ from the $b c$ plane, and the molecules are stacked in a coplanar arrangement along the unit cell $a$ axis with an intermolecular distance equal to the $a$ axial length.

Optical and IR Spectra. The electronic spectra of $\mathrm{Ru}(\mathrm{R}-$ salen $)(\mathrm{X})(\mathrm{NO})$ compounds $\mathbf{I}-\mathbf{I V}$ in acetonitrile solutions are displayed in Figure 4. For each there are strong ligand localized $\pi-\pi^{*}$ UV absorptions (not shown) seen also for the free ligands (Supporting Information Table S-1). In the near-UV, the salen complexes I and II display a strong band with $\lambda_{\max }$ at 370 and $376 \mathrm{~nm}$, respectively, while the ${ }^{t} \mathrm{Bu}_{4}$ salen complexes III and IV display similar bands at 390 and 394 $\mathrm{nm}$. This band is moderately solvent sensitive. For the free ligands a weaker band assigned to an $n-\pi^{*}$ transition (where " $n$ " is the nonbonding orbital of the nitrogen lone pair electrons) occurs in this region. ${ }^{30}$ However, salen coordination involves the $\sigma$-donation of nitrogen lone pair, so this orbital would be substantially stabilized. Accordingly, the $\mathrm{n}-\pi^{*}$ band is found at $406 \mathrm{~nm}$ for free salen $\mathrm{H}_{2}$, while the near-UV $\lambda_{\max }$ are found at 370 and $376 \mathrm{~nm}$ for I and II, respectively, in acetonitrile. Although the blue-shift seen

(30) Khan, M. M. T.; Shaikh, Z. A.; Kureshy, R. I.; Boricha, A. B. Polyhedron 1992, 11, 91-100. 


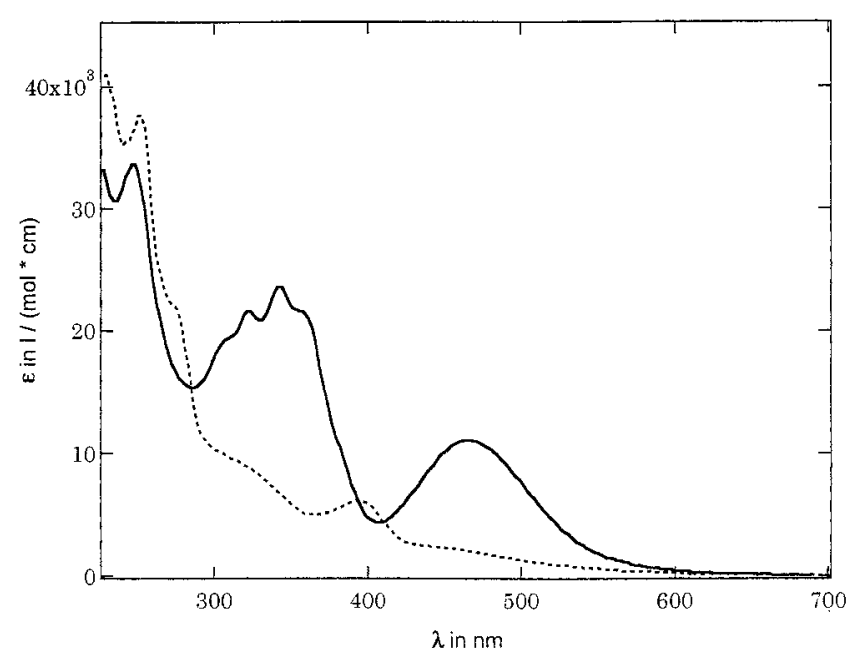

Figure 5. Quantitative comparison of the electronic spectra of $\mathrm{Ru}-$ $\left({ }^{t} \mathrm{Bu}_{4}\right.$ salen $)(\mathrm{Cl})(\mathrm{NO})(\mathbf{I I I})$ and $\mathrm{Ru}\left({ }^{t} \mathrm{Bu}{ }_{4}\right.$ salophen $)(\mathrm{Cl})(\mathrm{NO})(\mathrm{VI})$ in acetonitrile.

would be in accord with a $\sigma-\pi^{*}$ assignment, a larger shift might be anticipated, and the high extinction coefficients $\left(\sim(5-11) \times 10^{3} \mathrm{M}^{-1} \mathrm{~cm}^{-1}\right)$ suggest charge-transfer character. Consistent with a metal-to-ligand charge transfer (MLCT) assignment is the observation that $\mathbf{V}$ and $\mathbf{V I}$ with the more delocalized salophen ligands display strong bands with $\lambda_{\max }$ at 458 and $468 \mathrm{~nm}$ in acetonitrile (e.g., Figure 5). ${ }^{31,32}$ However, the salen complexes I-IV themselves display significant absorption at these longer wavelengths with intensities sufficient to suggest charge-transfer character. Even the simple cationic ruthenium amine complex $\mathrm{Ru}\left(\mathrm{NH}_{3}\right)_{5}-$ $(\mathrm{NO})^{3+}$ displays a broad, low-energy band $\left(\lambda_{\max } \sim 460 \mathrm{~nm}\right)$ which has been assigned as a $\mathrm{d}_{\pi}(\mathrm{Ru}) \rightarrow \pi^{*}(\mathrm{NO})$, but this is by comparison very weak $\left(\epsilon<10^{2} \mathrm{M}^{-1} \mathrm{~cm}^{-1}\right)$. Since the ligands used to prepare I-VI do not show visible absorptions, the tailing of the spectra of $\mathbf{I}-\mathbf{I V}$ into the visible may be best explained terms of a charge-transfer transition (MLCT being the most likely) although this may also have $\mathrm{d}_{\pi}(\mathrm{Ru}) \rightarrow \pi^{*}(\mathrm{NO})$ or ligand (phen-oxo) $\rightarrow \pi^{*}(\mathrm{NO})$ character as well. ${ }^{32}$

In the FTIR spectra, the $v_{\mathrm{NO}}$ bands for complexes I-VII all fall in the $1832-1856 \mathrm{~cm}^{-1}$ range. The only exception is the $[\mathrm{Ru}(\text { salen })(\mathrm{NO})]_{2} \mathrm{O}$ dimer at $1762 \mathrm{~cm}^{-1}$.

Photochemistry of the Nitrosyl Complexes. When solutions of the ruthenium salen nitrosyl complexes $\mathbf{I}-\mathbf{I V}$ and the salophen analogues $\mathbf{V}$ and $\mathbf{V I}$ were subjected to continuous photolysis, the resulting optical spectral changes were consistent with substitution of NO by a solvent molecule (eq 4). For example, Figure 6 illustrates the spectral changes seen when an acetonitrile solution of $\mathbf{I}(\sim 0.011 \mathrm{mM})$ was irradiated at $\lambda_{\text {irr }}=365 \mathrm{~nm}$. This displays a clean transforma-

(31) On the other hand. the MLCT assignment would appear inconsistent with the shifts seen upon ${ }^{t} \mathrm{Bu}$ substitution of these ligands, since ${ }^{t} \mathrm{Bu}$ is more electron donating than $\mathrm{H}$. Another possibility that has been discussed in other complexes are ligand (L) to ligand (NO) charge transfers (LLCT). ${ }^{32 \mathrm{c}}$

(32) (a) Schreiner, A. F.; Lin, S. W.; Hauser, P. J. Hopcus, E. A. Hamm, D. J.; Gunter, J. D. Inorg. Chem. 1972, 11, 880-888. (b) Boggs, S E. Ph.D. Dissertation, University of California, Santa Barbara, CA 1996. (c) Gorelsky, S. I.; DaSilva, S. C.; Lever, A. B. P., Franco, D. W. Inorg. Chim. Acta 2000, 300, 698-708. (d) Gorelsky, S. I.; Lever, A. B. P. Int. J. Quantum Chem. 2000, 80, 636-645

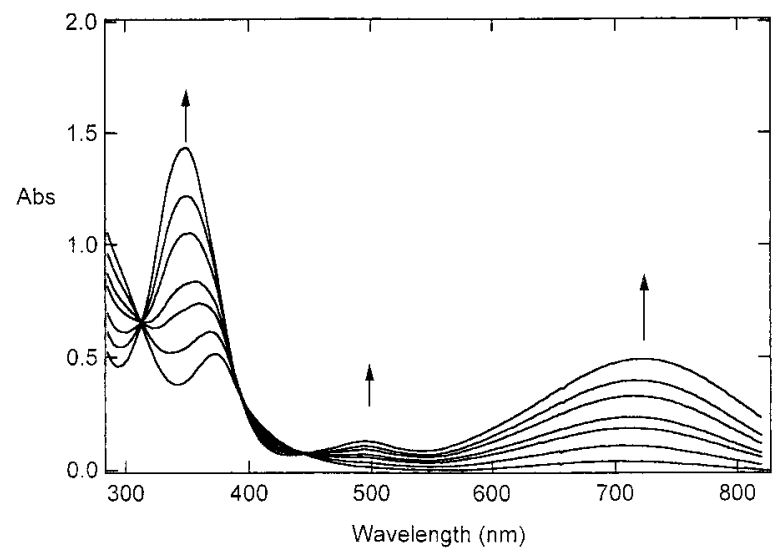

Figure 6. Spectral changes observed for $\mathrm{Ru}(\mathrm{salen})(\mathrm{ONO})(\mathrm{NO})$ (I) during $365 \mathrm{~nm}$ continuous photolysis in acetonitrile solution at room temperature. Isosbestic behavior is observed at 313,444 , and $\sim 394 \mathrm{~nm}$.

tion, characterized by isosbestic points at 313,392 , and 448 $\mathrm{nm}$, to give a photoproduct with increased absorbance at 348 $\mathrm{nm}$ and new bands appearing at 494 and $724 \mathrm{~nm}$. Exhaustive photolysis leads to a final stable spectrum. On the basis of the assumption that a single product was formed (see below), the extinction coefficients of the respective bands were calculated as $1.5 \times 10^{4}, 1.3 \times 10^{3}$, and $5.0 \times 10^{3} \mathrm{M}^{-1} \mathrm{~cm}^{-1}$. Longer wavelength bands similar to that at $724 \mathrm{~nm}$ have been reported previously for $\mathrm{Ru}(\mathrm{III})$ salen complexes and were assigned as ligand (phen-oxo) to metal (Ru(III)) chargetransfer (LMCT) bands. ${ }^{33}$ The LMCT band proved to be moderately solvent dependent.

$$
\begin{aligned}
& \mathrm{Ru}(\mathrm{L})(\mathrm{X})(\mathrm{NO})+\mathrm{Sol} \stackrel{\mathrm{h} v}{\longrightarrow} \mathrm{Ru}(\mathrm{L})(\mathrm{X})(\mathrm{Sol})+\mathrm{NO} \\
& \mathrm{L}=\mathrm{R} \text {-salen }{ }^{2-}, \mathrm{R}_{\text {-salophen }}{ }^{2-} ; \mathrm{X}=\mathrm{Cl}^{-}, \mathrm{ONO}^{-}
\end{aligned}
$$

When analogous $365 \mathrm{~nm}$ photolysis of an acetonitrile solution of $\mathbf{I}$ in a $0.2 \mathrm{~mm}$ path length $\mathrm{CaF}_{2}$ cell was monitored by FTIR spectroscopy, the $v_{\mathrm{NO}}$ IR band at $1850 \mathrm{~cm}^{-1}$ disappeared, and no new band appeared in this region. The imine $(\mathrm{C}=\mathrm{N})$ band at $1636 \mathrm{~cm}^{-1}$ shifted to $1610 \mathrm{~cm}^{-1}$. The $\mathrm{UV}$-vis spectral changes of this solution recorded in the $\mathrm{CaF}_{2}$ cell paralleled those described above, and plots of optical spectra band intensity changes versus changes in the IR band intensities were linear implying a one-to-one correspondence. When the photolysis was carried out under NO $\left(P_{\mathrm{NO}}=1 \mathrm{~atm}\right)$, the same photoproducts were observed; however, over several hours the starting spectrum was regenerated. Thus, photolysis of $\mathbf{I}$ in acetonitrile apparently leads solely to reversible NO photolabilization as described in eq 1.

Continuous photolysis experiments carried out for compounds II-VI led to analogous spectra changes in various solvents. (For example, Supporting Information Figures S-3 and S-4 display the spectral changes resulting from photolysis of the salophen complex V.) Spectra of the photoproducts from I-IV are shown in Figure 7. In each case, a band in the 700-800 $\mathrm{nm}$ range characteristic of a $\mathrm{Ru}(\mathrm{III})$ salen complex was observed in accord with $\mathrm{NO}$ dissociation from the diamagnetic $\mathrm{Ru}(\mathrm{L})(\mathrm{X})(\mathrm{NO})$ starting material. Further

(33) Leung, W. H.; Che, C. M. Inorg. Chem. 1989, 28, 4619-4622. 
Table 5. Quantum Yields for NO Labilization $\Phi_{\mathrm{NO}}{ }^{a}$ from $\mathrm{Ru}(\mathrm{L})(\mathrm{X})(\mathrm{NO})$ in $298 \mathrm{~K}$ Acetonitrile Solution Measured for Continuous Photolysis at Different Irradiation Wavelengths

\begin{tabular}{|c|c|c|c|}
\hline $\mathrm{Ru}(\mathrm{L})(\mathrm{X})(\mathrm{NO})$ & $\begin{array}{c}\Phi_{\mathrm{NO}}\left(\lambda_{\text {irr }}=365 \mathrm{~nm}\right) \\
(\mathrm{mol} / \text { einstein })\end{array}$ & $\begin{array}{c}\Phi_{\mathrm{NO}}\left(\lambda_{\text {irr }}=436 \mathrm{~nm}\right) \\
(\mathrm{mol} / \text { einstein })\end{array}$ & $\begin{array}{c}\Phi_{\mathrm{NO}}\left(\lambda_{\text {irr }}=546 \mathrm{~nm}\right) \\
(\text { mol/einstein })\end{array}$ \\
\hline $\mathrm{Ru}($ salen$)(\mathrm{ONO})(\mathrm{NO})(\mathbf{I})$ & $0.067 \pm 0.002$ & $0.058 \pm 0.002$ & \\
\hline $\mathrm{Ru}($ salen $)(\mathrm{Cl})(\mathrm{NO})(\mathbf{I I})$ & $0.13 \pm 0.01$ & $0.09 \pm 0.01$ & $0.07 \pm 0.02$ \\
\hline $\mathrm{Ru}\left({ }^{t} \mathrm{Bu}_{4} \mathrm{salen}\right)(\mathrm{Cl})(\mathrm{NO})(\mathrm{III})$ & $0.030 \pm 0.002$ & $0.040 \pm 0.002$ & $0.020 \pm 0.001$ \\
\hline $\mathrm{Ru}\left({ }^{t} \mathrm{Bu}_{2} \mathrm{salophen}\right)(\mathrm{Cl})(\mathrm{NO})(\mathrm{V})$ & $0.077 \pm 0.008^{b}$ & $0.033 \pm 0.002$ & $0.014 \pm 0.001$ \\
\hline $\mathrm{Ru}\left({ }^{t} \mathrm{Bu}_{4}\right.$ salophen $)(\mathrm{Cl})(\mathrm{NO})(\mathrm{VI})$ & $0.055 \pm 0.003$ & $0.027 \pm 0.002$ & $0.011 \pm 0.002$ \\
\hline$\left[\mathrm{Ru}(\right.$ salen $\left.)\left(\mathrm{H}_{2} \mathrm{O}\right)(\mathrm{NO})\right] \mathrm{Cl}(\mathbf{V I I})$ & $0.005 \pm 0.001^{c}$ & & \\
\hline
\end{tabular}

${ }^{a}$ All quantum yield values were determined from averaged of 3 or more independent measurements. ${ }^{b}$ For 365 nm irradiation of $\mathbf{V} \Phi_{\mathrm{NO}}$ was $0.043 \pm$ 0.004 in methanol and $0.046 \pm 0.006$ in tetrahydrofuran. ${ }^{c}$ Measured in aqueous solution.

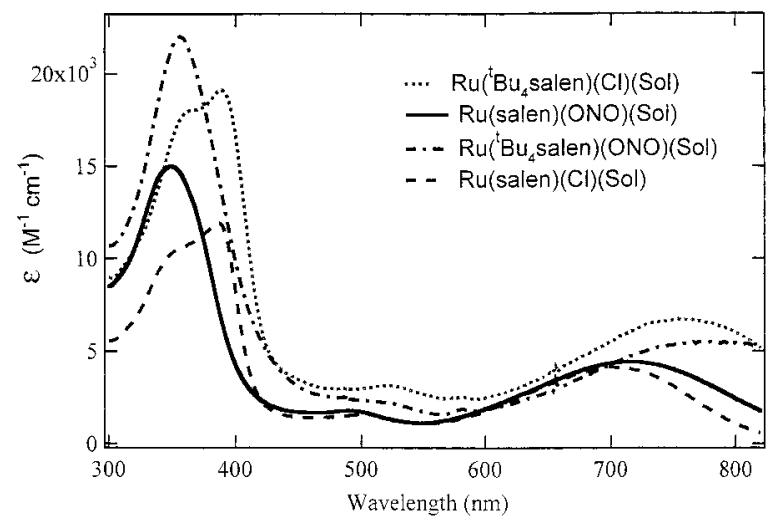

Figure 7. Photoproduct spectra observed after exhaustive photolysis of acetonitrile solutions of nitrosyl complexes I-IV.

evidence regarding the identity of the photoproducts can be drawn from changes in the ${ }^{1} \mathrm{H}$ NMR spectra. Before photolysis, solutions of these materials display NMR spectra with sharp and characteristic proton resonances, but $365 \mathrm{~nm}$ photolysis leads to peak broadening and eventually to spectra consistent with paramagnetic $\mathrm{Ru}(\mathrm{III})$ compounds.

Photoinduced spectral changes similar to those seen in acetonitrile were observed in THF and dichloromethane solutions. (See Supporting Information Tables S-2 and S-3, which list photoproduct spectra for II and III in different solvents.) When the photolyses were carried out in aerated solutions, the spectral changes were permanent; however, in deaerated solutions or under $\mathrm{NO}$, the photoproducts underwent back-reaction to regenerate the starting complexes. The rates of regeneration proved to be strongly dependent on the solvent as well as on [NO], and quantitative studies of these systems are described below. Notably, when photolyses were carried out in deaerated solutions of cyclohexane or toluene, there were no observable spectra changes indicating the formation of photoproducts. As will be delineated below, this is the result of very fast back-reaction rather than the absence of photoreactivity.

The relatively slow back-reactions in donor solvents such as acetonitrile allowed for the determination of the NO labilization quantum yield $\left(\Phi_{\mathrm{NO}}\right)$ on the basis of spectral changes and the calculated product extinction coefficients. For $\mathbf{I}$ in acetonitrile, $\Phi_{\mathrm{NO}}$ determined in this manner was 0.067 for $365 \mathrm{~nm}$ irradiation and $0.058 \pm 0.002$ for $436 \mathrm{~nm}$ excitation. In general, $\Phi_{\mathrm{NO}}$ decreases at longer $\lambda_{\text {irr }}$ but the complexes remain photoactive even at the longest $\lambda_{\text {irr }}$ studied $(546 \mathrm{~nm})$ (Table 5). This pattern suggests that the NO labilization may result from population of a dissociative excited state (ES) or one with a relatively low barrier for dissociation, a likely candidate being the mixed $d-\pi^{*}(\mathrm{NO}) /$ $\mathrm{d}-\mathrm{d}$ state assigned as the lowest energy ES of the simple ruthenium amine nitrosyl complexes. ${ }^{32}$ However, in the absence of more detailed photophysical and theoretical studies of such systems, this proposal is largely speculative.

In an earlier report from this laboratory, Lorkovic et al. ${ }^{8}$ described the photochemistry of the nitrito nitrosyl ruthenium porphyrin systems $\mathrm{Ru}(\mathrm{P})(\mathrm{ONO})(\mathrm{NO})(\mathrm{P}=\mathrm{TPP}$ or $\mathrm{OEP})$ and showed that the $\mathrm{NO}_{2}$ as well as $\mathrm{NO}$ dissociates upon photolysis (eq 5). In the case of $\mathrm{NO}_{2}$ dissociation, the parent $\mathrm{Ru}(\mathrm{P})(\mathrm{ONO})(\mathrm{NO})$ compounds were regenerated under excess $\mathrm{NO}$ via a disproportionation pathway that also gives $\mathrm{N}_{2} \mathrm{O}$, which was quantified by its IR band at $2220 \mathrm{~cm}^{-1}$ (toluene). ${ }^{34}$ (An analogous disproportionation may be responsible for formation of nitrito ligands in the syntheses of $\mathbf{I}^{23}$ ) In contrast, the spectral changes seen upon photolysis of the nitrito nitrosyl complexes $\mathbf{I}$ and $\mathbf{I V}$, as well as the kinetics behaviors of the photoproducts, gave no suggestion that $\mathrm{NO}_{2}$ photodissociation was a competing pathway with NO photodissociation. Nonetheless, to test this possibility toluene and cyclohexane solutions of IV under excess NO ( 300 Torr) were photolyzed $(365 \mathrm{~nm})$ in a $\mathrm{CaF}_{2}$ cell and the IR spectra monitored periodically. Difference spectra indicated no absorbance changes at $2220 \mathrm{~cm}^{-1}$ hence not any formation of $\mathrm{N}_{2} \mathrm{O}$. NO dissociation is apparently the only photoreaction for the salen type complexes under the conditions studied here.

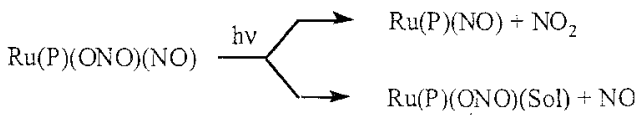

Thus, the photochemistry of each of these salen and salophen complexes is dominated by the simple dissociation of NO as described by eqs 1 and 4. Photodissociation of NO generates the $\mathrm{Ru}(\mathrm{III})$ solvento complex $\mathrm{Ru}(\mathrm{L})(\mathrm{X})(\mathrm{Sol})$, and this species must be that responsible for the photolysis promoted catalysis by $\mathrm{Ru}(\mathrm{L})(\mathrm{X})(\mathrm{NO})$ solutions of various organic transformations including hetero-Diels-Alder reactions, alkene expoxidations, and cyclopropanations. ${ }^{20}$ It further seems likely that the Lewis acid catalysis of DielsAlder reactions reported previously ${ }^{21}$ for $\mathrm{Ru}($ salen $)\left(\mathrm{H}_{2} \mathrm{O}\right)$ $(\mathrm{NO})^{+}$and attributed to the electron-withdrawing properties of NO may have included contributions from inadvertent NO

(34) Lorkovic, I. M.; Ford, P. C. Inorg. Chem. 1999, 38, 1467-1473. 


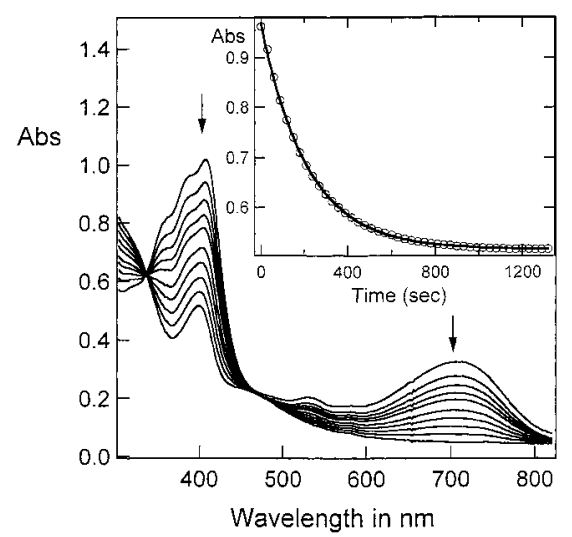

Figure 8. Spectral changes seen for the back-reaction of $\mathrm{Ru}\left({ }^{t} \mathrm{Bu}_{4} \mathrm{salen}\right)$ $(\mathrm{Cl})(\mathrm{THF})$ with $\mathrm{NO}(7.5 \mathrm{mM})$ to give III in $298 \mathrm{~K}$ THF solution. Inset: Decay of the absorbance at $408 \mathrm{~nm}$ and the fit to an exponential function to give $k_{\mathrm{obs}} 4.65 \times 10^{-3} \mathrm{~s}^{-1}$.

labilization from this photolabile species. The participation of the solvento species is further consistent with the qualitative observations that catalysis rates are markedly solvent sensitive; ${ }^{20.21}$ for example, acetonitrile strongly inhibited Diels-Alder reaction catalysis by VII. ${ }^{21}$

Thermal Substitution Mechanisms. Reaction of NO with Solvento Ru(III) Photoproducts. The photochemical generation of the $\mathrm{Ru}(\mathrm{L})(\mathrm{X})(\mathrm{Sol})$ photoproducts provides the opportunity to investigate the kinetics and other details of the substitution reactions to regenerate $\mathrm{Ru}(\mathrm{L})(\mathrm{X})(\mathrm{NO})$ (e.g., eq 6). For donor solvents such as acetonitrile and tetrahydrofuran, even dichloromethane, these rates were sufficiently slow to study using conventional spectrophotometric techniques, and back-reactions appeared quantitative for each system investigated. For example, Figure 8 displays the spectral changes seen for the back-reaction of $\mathrm{Ru}\left({ }^{t} \mathrm{Bu}_{4}\right.$ salen $)$ (Cl)(THF) with NO (7.5 mM) in $298 \mathrm{~K}$ THF solution. Clean isosbestic points at 338 and $467 \mathrm{~nm}$ are evident, and the spectrum evolves quantitatively to that of $\mathrm{Ru}\left({ }^{t} \mathrm{Bu} \mathrm{u}_{4}\right.$ salen $)(\mathrm{Cl})$ (NO) (III).

$$
\begin{aligned}
& \mathrm{Ru}\left({ }^{t} \mathrm{Bu}_{4} \text { salen }\right)(\mathrm{Cl})(\mathrm{THF})+\mathrm{NO} \stackrel{k_{\mathrm{NO}}}{\longrightarrow} \\
& \mathrm{Ru}\left({ }^{t} \mathrm{Bu}_{4} \text { salen }\right)(\mathrm{Cl})(\mathrm{NO})+\mathrm{THF}
\end{aligned}
$$

The kinetics of this reaction is illustrated by the temporal absorbance decay at $408 \mathrm{~nm}$ shown in the Figure 8 inset, which was fit to an exponential function to give the $k_{\text {obs }}$ value $4.65 \times 10^{-3} \mathrm{~s}^{-1}$. The values of $k_{\mathrm{obs}}$ obtained in this manner were dependent on the NO concentration. A plot of $k_{\mathrm{obs}} \mathrm{vs}$ [NO] proved to be linear with an intercept of zero within experimental uncertainty (Figure 9). Thus, the reaction follows second-order kinetics (eq 7), and the slope of this plot $\left(0.57 \pm 0.07 \mathrm{M}^{-1} \mathrm{~s}^{-1}\right)$ is the second-order rate constant $k_{\mathrm{NO}}$.

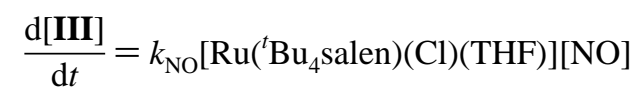

Analogous kinetics behavior was seen for other $\mathrm{Ru}(\mathrm{L})(\mathrm{X})$ (Sol) complexes in $\mathrm{CH}_{3} \mathrm{CN}$, THF, and $\mathrm{CH}_{2} \mathrm{Cl}_{2}$. Values of $k_{\mathrm{NO}}$ determined at $298 \mathrm{~K}$ in these solvents are listed in Table 6.

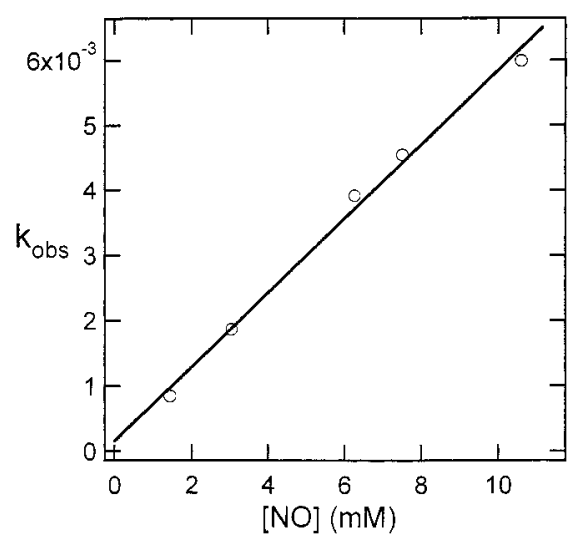

Figure 9. Plot of $k_{\mathrm{obs}}$ values for the back reaction of $\mathrm{Ru}\left({ }^{t} \mathrm{Bu} 4 \mathrm{salen}\right)(\mathrm{Cl})$ (THF) with $\mathrm{NO}$ to give III determined in $298 \mathrm{~K}$ THF vs [NO]. $k_{\mathrm{NO}}=$ $0.57( \pm 0.07) \mathrm{M}^{-1} \mathrm{~s}^{-1}$.

As noted above, there appeared to be little or no net reaction when the $\mathrm{Ru}(\mathrm{L})(\mathrm{X})(\mathrm{NO})$ complexes were subjected to continuous photolysis in hydrocarbon solvents such as toluene and cyclohexane. While it is possible that these systems are simply not photoactive, it seemed more likely that back-reactions occur too rapidly under these conditions to observe transient solvento complexes using conventional spectroscopic techniques. To test the latter proposition, several complexes in hydrocarbon solutions were subjected to flash photolysis using time-resolved optical (TRO) detection on the microsecond time scale. Indeed, reactive intermediates with spectra consistent with those seen in other solvents were thus observed. For example, the flash photolysis of $\mathrm{Ru}\left({ }^{t} \mathrm{Bu}_{4} \mathrm{Salen}\right)(\mathrm{Cl})(\mathrm{NO})$ in toluene gave a transient difference spectrum (Figure 10) displaying the LMCT absorption band characteristic of a $\mathrm{Ru}(\mathrm{III})$ salen complex, e.g. $\mathrm{Ru}\left({ }^{t} \mathrm{Bu}_{4} \mathrm{Salen}\right)(\mathrm{Cl})(\mathrm{Sol})$. The decay of this in the presence of excess NO showed two regimes, one quite fast leading to a residual absorbance, followed by a very slow decay of the latter to baseline. The magnitude of the residual proved to be dependent on the amount of $\mathrm{H}_{2} \mathrm{O}$ present, i.e., very small in "dry" toluene but larger in toluene to which $\mathrm{H}_{2} \mathrm{O}$ had been added, so the residual is likely to be due to the long-lived intermediate $\mathrm{Ru}\left({ }^{t} \mathrm{Bu}_{4} \mathrm{Salen}\right)(\mathrm{Cl})\left(\mathrm{H}_{2} \mathrm{O}\right)$ formed by the competitive trapping of $\mathrm{Ru}\left({ }^{t} \mathrm{Bu}_{4}\right.$ Salen $)(\mathrm{Cl})(\mathrm{Sol})$ by $\mathrm{H}_{2} \mathrm{O}$ (Scheme 2$)$. The fast decay process was first order under excess $\mathrm{NO}$, and the $k_{\mathrm{obs}}$ values determined were a linear function of [NO] at each temperature studied (Figure 11). From the slope of such a plot $k_{\mathrm{NO}}=2.20( \pm 0.05) \times 10^{7} \mathrm{M}^{-1} \mathrm{~s}^{-1}$ was obtained for the reaction of $\mathrm{Ru}\left({ }^{t} \mathrm{Bu}_{4}\right.$ salen $)(\mathrm{Cl})(\mathrm{Sol})$ with $\mathrm{NO}$ in $298 \mathrm{~K}$ toluene solution. Thus, this reaction is $\sim 8$ orders of magnitude faster in toluene than in THF. When flash photolysis of $\mathrm{Ru}\left({ }^{t} \mathrm{Bu}_{4}\right.$ salen $)(\mathrm{Cl})(\mathrm{NO})$ was carried out in cyclohexane, the value of $k_{\mathrm{NO}}$ was another factor of 20 higher (Table 6).

Each of the compounds studied displayed comparable behavior. The values of $k_{\mathrm{NO}}$ determined for the $\mathrm{Ru}(\mathrm{III})$ complexes $\mathrm{Ru}(\mathrm{L})(\mathrm{X})(\mathrm{Sol})$ in various solvents are listed in Table 6.

Activation Parameters for Substitution Reactions. Temperature effects on the kinetics of selected complexes and solvent systems were probed by determining the first- 
Works et al.

Table 6. Second-Order Rate Constants $k_{\mathrm{NO}}$ for Reaction of $\mathrm{Ru}(\mathrm{L})(\mathrm{X})(\mathrm{Sol})$ with $\mathrm{NO}$ in Various Solvents (Sol) at $298 \mathrm{~K}^{a}$

\begin{tabular}{|c|c|c|c|c|c|}
\hline \multirow[b]{2}{*}{$\mathrm{Ru}(\mathrm{L})(\mathrm{X})(\mathrm{Sol})$} & \multicolumn{5}{|c|}{$k_{\mathrm{NO}}\left(\mathrm{M}^{-1} \mathrm{~s}^{-1}\right)$ values in different $298 \mathrm{~K}$ solvents } \\
\hline & $\mathrm{Sol}=\mathrm{CH}_{3} \mathrm{CN}$ & Sol $=\mathrm{THF}$ & $\mathrm{Sol}=\mathrm{CH}_{2} \mathrm{Cl}_{2}$ & Sol $=$ toluene & Sol $=$ cyclohexane \\
\hline $\mathrm{L}=$ salen $; \mathrm{X}=\mathrm{Cl}$ & $4.7( \pm 0.3) \times 10^{-4}$ & $0.22( \pm 0.07)$ & $6.7( \pm 0.4)$ & $3.7( \pm 0.3) \times 10^{7}$ & \\
\hline${ }^{t} \mathrm{Bu}_{4}$ salen; $\mathrm{Cl}$ & $9.2( \pm 0.2) \times 10^{-4}$ & $0.57( \pm 0.07)$ & & $2.2( \pm 0.1) \times 10^{7}$ & $5.0( \pm 0.2) \times 10^{8}$ \\
\hline${ }^{t} \mathrm{Bu}_{4}$ salen; ONO & $7.2( \pm 0.3) \times 10^{-2}$ & & & & $2.6( \pm 0.3) \times 10^{6}$ \\
\hline${ }^{t} \mathrm{Bu}_{2}$ salophen; $\mathrm{Cl}$ & & $0.19( \pm 0.03)$ & & $5.3( \pm 0.5) \times 10^{6}$ & \\
\hline${ }^{{ }^{t} \mathrm{Bu}} \mathrm{u}_{4}$ salophen; $\mathrm{Cl}$ & $3.1( \pm 0.1) \times 10^{-3}$ & $0.18( \pm 0.02)$ & & $9.2( \pm 0.5) \times 10^{6}$ & \\
\hline
\end{tabular}

${ }^{a} k_{\mathrm{NO}}$ values were determined from the slopes of linear plots of $k_{\mathrm{obs}} \mathrm{vs}[\mathrm{NO}]$ for $4-7 \mathrm{NO}$ concentrations in each solvent.

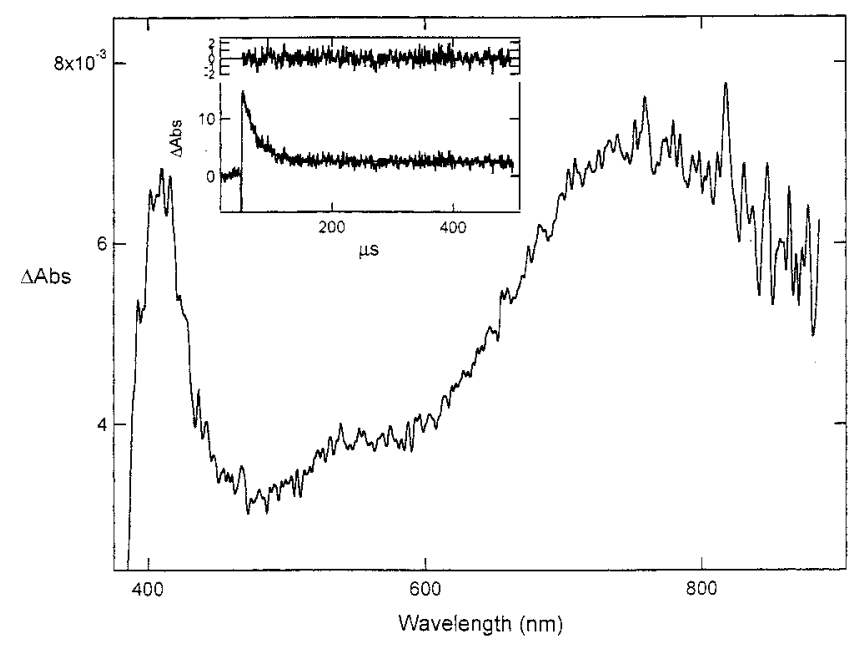

Figure 10. CCD spectrum of the transient species generated from $\mathrm{Ru}\left({ }^{t} \mathrm{Bu}_{4}\right.$ salen $)(\mathrm{NO})(\mathrm{Cl})$ during laser flash photolysis in toluene under excess NO (611 Torr). The spectrum was collected at $25^{\circ} \mathrm{C}$, and the excitation wavelength was $355 \mathrm{~nm}$. The delay time was $400 \mathrm{~ns}$ (the laser pulse had a $10 \mathrm{~ns}$ lifetime), and the gate was $2 \mu \mathrm{s}$.

\section{Scheme 2}

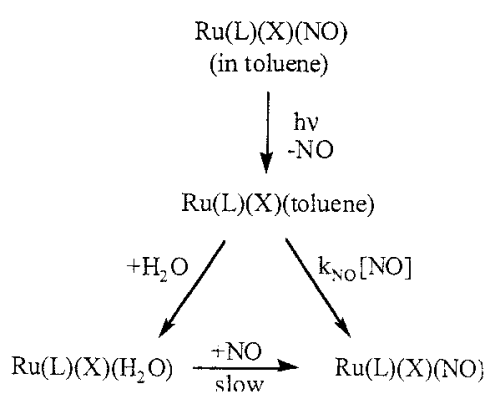

order rate constants at several NO concentrations and plotting these to obtain values of $k_{\mathrm{NO}}$ for specific $T$ s. For example, Figure 11 illustrates plots for the reaction of $\mathrm{Ru}\left({ }^{t} \mathrm{Bu}_{4} \mathrm{salen}\right)$ $(\mathrm{Cl})(\mathrm{Sol})$ with NO in toluene. An Eyring plot of these data (Figure 11 inset) gave $\Delta H_{\mathrm{NO}}{ }^{\ddagger}=34 \pm 2 \mathrm{~kJ} / \mathrm{mol}$ and $\Delta S_{\mathrm{NO}}{ }^{\ddagger}$ $=+10 \pm 6 \mathrm{~J} \mathrm{~K}^{-1} \mathrm{~mol}^{-1}$. Activation parameters obtained from such temperature dependence studies for several complexes in toluene by flash photolysis experiments and in acetonitrile by conventional spectrophotometry are summarized in Table 7. The notable observation here is that the $\Delta H$ values are very solvent dependent, more than twice as large for Sol $=$ acetonitrile as for Sol $=$ toluene. The greater $\Delta H_{\mathrm{NO}}{ }^{\ddagger}$ value for the stronger donor solvent argues that $\mathrm{Ru}-$ Sol bond breaking must be important in the reaction mechanisms for NO substitution for Sol.

Hydrostatic pressure effects were also investigated, but the configuration of our apparatus limited such studies to the faster reactions that could be investigated by laser flash

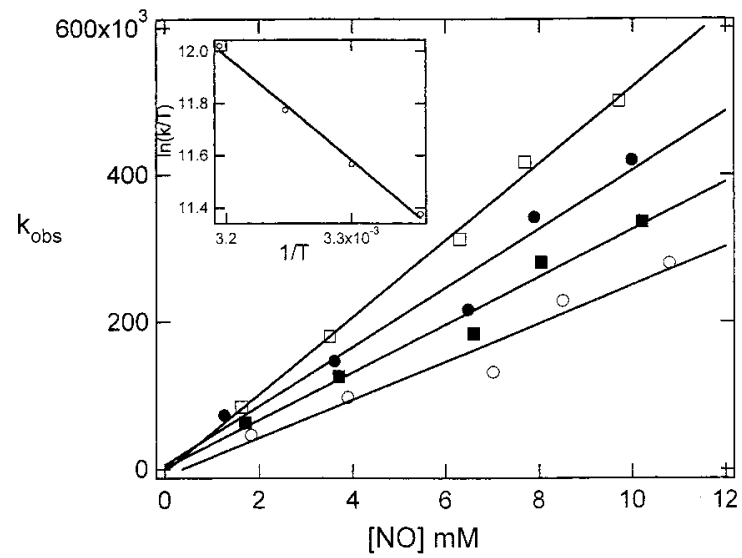

Figure 11. Plots of $k_{\mathrm{obs}}$ values vs [NO] for the back-reaction of $\left.\mathrm{Ru}^{t}{ }^{t} \mathrm{Bu}_{4} \mathrm{salen}\right)(\mathrm{Cl})(\mathrm{Sol})$ with $\mathrm{NO}$ to give III determined in toluene at 298 , 303,308 , and $313 \mathrm{~K}$. An Eyring plot of these data (inset) gave $\Delta H_{\mathrm{NO}}{ }^{\ddagger}=$ $34 \pm 2 \mathrm{~kJ} / \mathrm{mol}$ and $\Delta S_{\mathrm{NO}}{ }^{\ddagger}=+10 \pm 6 \mathrm{~J} \mathrm{~K}^{-1} \mathrm{~mol}^{-1}$.

photolysis, that is, the back-reactions of the photoproducts of III, $\mathbf{V}$, and VI in toluene. The volume of activation for a reaction rate is defined by eq $8 .^{26}$ Thus, a plot of $\ln k_{\text {obs }}$ at a fixed [NO] vs the hydrostatic pressure $P$ as shown in Figure 12 for the $\mathrm{NO}$ reaction with $\mathrm{Ru}\left({ }^{t} \mathrm{Bu}_{4} \mathrm{Salen}\right)(\mathrm{Cl})(\mathrm{Sol})$ in toluene has a slope equal to $-\Delta V_{\mathrm{NO}}^{\ddagger} / R T$. In cases reported here, rates decreased sharply with increasing pressure; hence, the activation volumes $\Delta V_{\mathrm{NO}}{ }^{\ddagger}$ are large and positive (Table 7) consistent with a substitution mechanism with a dissociative character. $^{26 \mathrm{a}}$

$$
\Delta V_{i}^{*}=-R T\left(\frac{\mathrm{d}\left(\ln k_{i}\right)}{\mathrm{d} P}\right) T
$$

The kinetics of the $\mathrm{NO}$ reaction with $\mathrm{Ru}(\mathrm{L})(\mathrm{X})(\mathrm{Sol})$ to give $\mathrm{Ru}(\mathrm{L})(\mathrm{X})(\mathrm{NO})$ (eq 6) clearly suggest that the facility of this reaction is dependent on the lability of the leaving group. For a system such as $\mathrm{Ru}\left({ }^{t} \mathrm{Bu}_{4}\right.$ salen $)(\mathrm{Cl})(\mathrm{Sol})$ the range of $k_{\mathrm{NO}}$ values is more than 11 orders of magnitude from the slowest reaction in the donor solvent acetonitrile to the fastest in much weaker donor cyclohexane. The other systems probed show analogous behavior. The small $\Delta H_{\mathrm{NO}}{ }^{\ddagger}$ values seen in toluene solution and the larger ones seen in acetonitrile are consistent with this conclusion, and the large positive values of $\Delta V_{\mathrm{NO}}{ }^{\ddagger}$ recorded in toluene are strongly suggestive of a dissociative or dissociative interchange mechanism under these conditions. The $\Delta S_{\mathrm{NO}}{ }^{\ddagger}$ values are neither large and positive nor large and negative and show no clear trend. In this context we would favor an interchange mechanism perhaps dominated energetically by dissociation of Sol; however, a more detailed investigation would be required to provide a sounder foundation to that conclusion. 
Table 7. Temperature Effects on Second-Order Rate Constants $k_{\mathrm{NO}}$ for Reaction of Ru(L)(X)(Sol) with NO in Various Solvents ${ }^{a}$

\begin{tabular}{|c|c|c|c|c|c|}
\hline \multirow[b]{2}{*}{$T(\mathrm{~K})$} & \multicolumn{5}{|c|}{$k_{\mathrm{NO}}$ for different $\mathrm{Ru}(\mathrm{L})(\mathrm{X})(\mathrm{Sol})$} \\
\hline & $\begin{array}{c}\mathrm{L}={ }^{t} \mathrm{Bu}_{4} \text { salen, } \\
\mathrm{X}=\mathrm{Cl} \text { in acetonitrile }\end{array}$ & $\begin{array}{l}\mathrm{L}={ }^{t} \mathrm{Bu}_{4} \text { salen, } \\
\mathrm{Cl} \text { in toluene }\end{array}$ & $\begin{array}{c}\mathrm{L}={ }^{t} \mathrm{Bu}_{2} \text { salophen, } \\
\mathrm{Cl} \text { in toluene }\end{array}$ & $\begin{array}{c}\mathrm{L}={ }^{t} \mathrm{Bu}_{4} \text { salophen, } \\
\mathrm{Cl} \text { in acetonitrile }\end{array}$ & $\begin{array}{c}\mathrm{L}={ }^{t} \mathrm{Bu}_{4} \text { salophen, } \\
\mathrm{Cl} \text { in toluene }\end{array}$ \\
\hline 293 & & & $4.7( \pm 0.1) \times 10^{6}$ & & $7.8( \pm 0.1) \times 10^{6}$ \\
\hline 298 & $0.91( \pm 0.06) \times 10^{-3}$ & $2.5( \pm 0.4) \times 10^{7}$ & $5.7( \pm 0.1) \times 10^{6}$ & $3.1( \pm 0.1) \times 10^{-3}$ & $9.2( \pm 0.1) \times 10^{6}$ \\
\hline 303 & $1.9( \pm 0.1) \times 10^{-3}$ & $3.2( \pm 0.4) \times 10^{7}$ & $7.3( \pm 0.1) \times 10^{6}$ & $5.9( \pm 0.1) \times 10^{-3}$ & $10.7( \pm 0.2) \times 10^{6}$ \\
\hline 308 & $3.4( \pm 0.1) \times 10^{-3}$ & $3.9( \pm 0.5) \times 10^{7}$ & $10.4( \pm 0.5) \times 10^{6}$ & $10.1( \pm 0.1) \times 10^{-3}$ & $12.4( \pm 0.4) \times 10^{6}$ \\
\hline 313 & $7.0( \pm 0.1) \times 10^{-3}$ & $5.1( \pm 0.1) \times 10^{7}$ & $12.3( \pm 0.4) \times 10^{6}$ & $16.2( \pm 0.2) \times 10^{-3}$ & $14.6( \pm 0.2) \times 10^{6}$ \\
\hline 318 & $10.2( \pm 0.1) \times 10^{-3}$ & & & & \\
\hline$\Delta H^{\ddagger}\left(\mathrm{kJ} \mathrm{mol}^{-1}\right)$ & $87( \pm 8)$ & $34( \pm 2)$ & $36( \pm 3)$ & $82( \pm 4)$ & $20( \pm 1)$ \\
\hline$\Delta S^{\ddagger}\left(\mathrm{J} \mathrm{K}^{-1} \mathrm{~mol}^{-1}\right)$ & $-12 \pm 26$ & $+10 \pm 6$ & $+6 \pm 8$ & $-17 \pm 12$ & $-46 \pm 2$ \\
\hline$\Delta V^{\ddagger}(298 \mathrm{~K})\left(\mathrm{mL} \mathrm{mol}^{-1}\right)$ & & $+22 \pm 2$ & $+13 \pm 2$ & & $+16 \pm 2$ \\
\hline
\end{tabular}

${ }^{a} k_{\mathrm{NO}}$ values were determined from the slopes of linear plots of $k_{\mathrm{obs}} \mathrm{vs}[\mathrm{NO}]$ for $4-5 \mathrm{NO}$ concentrations in each solvent.

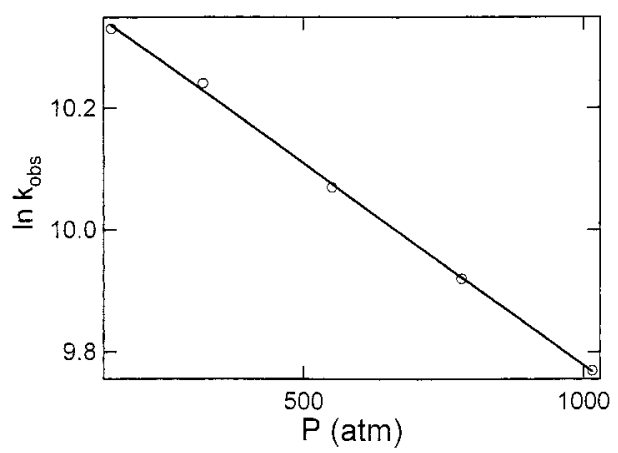

Figure 12. Plot of $\ln k_{\mathrm{obs}}$ at a fixed [NO] vs the hydrostatic pressure $P$ for the reaction of $\mathrm{Ru}\left({ }^{t} \mathrm{Bu}_{4} \mathrm{Salophen}\right)(\mathrm{Cl})(\mathrm{Sol})$ with $\mathrm{NO}$ in $298 \mathrm{~K}$ toluene solution. The slope is equal to $-\Delta V_{\mathrm{NO}}^{\ddagger} / R T$. From these data, a $\Delta V_{\mathrm{NO}}{ }^{\ddagger}$ value of $+16.2( \pm 0.4) \mathrm{mL} \mathrm{mol}^{-1}$ was calculated.

It should be noted that the patterns seen for the NO substitution mechanisms of the $\mathrm{Ru}(\mathrm{L})(\mathrm{X})(\mathrm{Sol})$ complexes described here appear to fall between the patterns seen for two related systems. The reaction of NO with aqueous $\mathrm{Ru}\left(\mathrm{NH}_{3}\right)_{6}{ }^{3+}$ to give $\mathrm{Ru}\left(\mathrm{NH}_{3}\right)_{5}(\mathrm{NO})^{3+}$ has been reported by Armor, Scheidegger, and Taube ${ }^{19 a}$ to be slow $\left(k_{\mathrm{NO}}=0.2\right.$ $\mathrm{M}^{-1} \mathrm{~s}^{-1}$ at $298 \mathrm{~K}$ ) but much faster than the substitution reactions of $\mathrm{Ru}\left(\mathrm{NH}_{3}\right)_{6}{ }^{3+}$ with other ligands under the same conditions, and an associative mechanism was proposed. Subsequent studies by Armor and Pell ${ }^{19 b}$ reported a very low activation enthalpy $\left(\Delta H_{\mathrm{NO}}{ }^{\ddagger}=34 \mathrm{~kJ} \mathrm{~mol}^{-1}\right)$ but a large and negative activation entropy $\left(\Delta S_{\mathrm{NO}}{ }^{\ddagger}=-120 \mathrm{~J} \mathrm{~mol}^{-1} \mathrm{~K}^{-1}\right)$ consistent with this conclusion. In contrast, the $\mathrm{Fe}(\mathrm{IIII})$ water soluble porphyrin complex $\mathrm{Fe}^{\mathrm{III}}(\mathrm{TPPS})\left(\mathrm{H}_{2} \mathrm{O}\right)_{2}$ reacts with aqueous $\mathrm{NO}$ to give $\mathrm{Fe}^{\mathrm{III}}$ (TPPS) $\left(\mathrm{H}_{2} \mathrm{O}\right)(\mathrm{NO})$ at a much faster rate $\left(k_{\mathrm{NO}}=4.5 \times 10^{5} \mathrm{M}^{-1} \mathrm{~s}^{-1} \text { at } 298 \mathrm{~K}\right)^{18 \mathrm{c}}$ with activation parameters suggesting a dissociative mechanism $\left(\Delta H_{\mathrm{NO}}{ }^{\ddagger}=\right.$ $69 \mathrm{~kJ} \mathrm{~mol}^{-1}, \Delta S_{\mathrm{NO}}^{\ddagger}=+95 \mathrm{~J} \mathrm{~mol}^{-1} \mathrm{~K}^{-1}, \Delta V_{\mathrm{NO}}{ }^{\ddagger}=+9 \mathrm{~mL}^{3}$ $\left.\mathrm{mol}^{-1}\right)$. Furthermore, the activation parameters closely parallel those for the rapid exchange $\left(k_{\mathrm{ex}}=1.4 \times 10^{7} \mathrm{~s}^{-1}\right.$ in 298 $\mathrm{K}$ water) between solvent and coordinated $\mathrm{H}_{2} \mathrm{O}$ of the labile $\mathrm{Fe}^{\mathrm{III}}(\mathrm{TPPS})\left(\mathrm{H}_{2} \mathrm{O}\right)_{2}$ complex.$^{35}$ Both systems involve $\mathrm{d}^{5}$ metal ion complexes, although the $\mathrm{Ru}(\mathrm{III})$ species are low spin whether or not $\mathrm{NO}$ is coordinated, while $\mathrm{Fe}^{\mathrm{III}}$ (TPPS) undergoes a transition from high to low spin when forming the nitrosyl complex. Nonetheless, the reactivity patterns for the $\mathrm{Ru}(\mathrm{L})(\mathrm{X})(\mathrm{Sol})$ complexes described here appear to follow

(35) (a) Ostrich, I. J.; Gordon, L.; Dodgen, H. W. Hunt, J. P. Inorg. Chem. 1980, 19, 619. (b) Schneppensieper, T.; Zahl, A; van Eldik, R. Angew. Chem., Int. Ed. 2001, 40, 1678-1680. more closely those of the Fe ${ }^{\mathrm{III}}$ (TPPS) system than that of $\mathrm{Ru}\left(\mathrm{NH}_{3}\right)_{6}{ }^{3+}$, namely that the kinetics of formation of the metal-NO species are dominated by the lability of the ligand being replaced.

Summary. The ruthenium nitrosyl complexes $\mathrm{Ru}(\mathrm{R}$ salen $)(\mathrm{X})(\mathrm{NO})$ and $\mathrm{Ru}(\mathrm{R}$-salophen $)(\mathrm{NO})(\mathrm{X}=\mathrm{Cl}$ or $\mathrm{ONO})$ all undergo NO labilization with moderate quantum yields when subjected to near-UV or visible photolysis as does the water soluble complex $\mathrm{Ru}($ salen $)\left(\mathrm{H}_{2} \mathrm{O}\right)(\mathrm{NO})^{+}$. Further studies will address the potential of these and related materials to serve as precursors for photochemical NO delivery to various targets. The other products of these photolyses in various solvents (Sol) are the $\mathrm{Ru}(\mathrm{III})$ solvent complexes $\mathrm{Ru}(\mathrm{R}$-salen)$(\mathrm{X})(\mathrm{Sol})$ and $\mathrm{Ru}(\mathrm{R}$-salophen)(Sol), and there is little or no labilization of other ligands in these photoreactions. It is likely that these ruthenium(III) complexes are the species responsible for the reported ${ }^{20}$ Lewis acid, oxene transfer, etc., catalysts formed upon photoactivation of $\mathrm{Ru}(\mathrm{R}$-salen)(X)(NO) precursors.

The rates of the back-reactions of the solvento products $\mathrm{Ru}(\mathrm{R}$-salen)(X)(Sol) and $\mathrm{Ru}(\mathrm{R}$-salophen)(Sol) with $\mathrm{NO}$ to re-form the nitrosyl analogues vary dramatically depending on the nature of Sol. The reactions are quite slow in donor solvents such as acetonitrile and THF but much faster in weak donors such as toluene and cyclohexane, second-order rate constants $k_{\mathrm{NO}}$ ranging from $5 \times 10^{-4} \mathrm{M}^{-1} \mathrm{~s}^{-1}$ for the re-formation of $\mathbf{I I}$ in acetonitrile to $5 \times 10^{8} \mathrm{M}^{-1} \mathrm{~s}^{-1}(12$ orders of magnitude) for re-formation of III in cyclohexane. Activation parameters are consistent with the view that the reactivities of these metal centers with $\mathrm{NO}$ are dominated by the labilities of the ligand being replaced and suggest that the ligand substitution occurs by a dissociative or dissociative interchange mechanism.

Acknowledgment. These studies were supported by the National Science Foundation (Grants CHE 9726889 and CHE 0095144). We thank Johnson-Matthey, Ltd., for a loan of the $\mathrm{RuCl}_{3}$ used in the syntheses. G.D.B. thanks the Howard Hughes Medical Institute for an undergraduate research fellowship.

Supporting Information Available: Figures S-1-S-4 and Tables S-1-S-3 as well as crystallographic information. This material is available free of charge via the Internet at http://pubs.acs.org.

IC020248K 